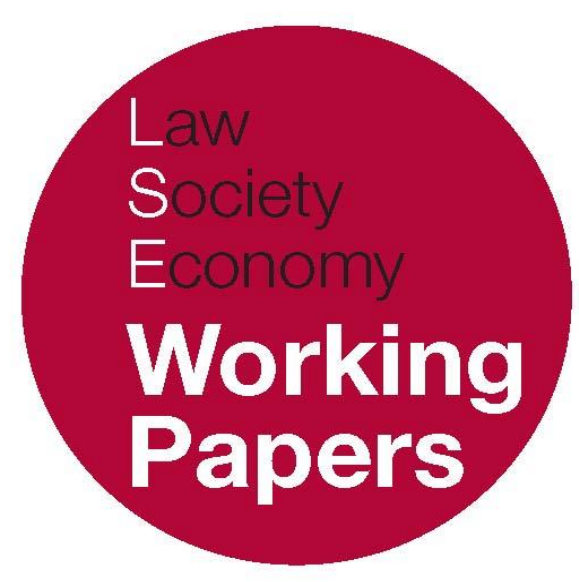

\title{
Bank Resolution Financing in the Banking Union
}

\section{Christos Hadjiemmanuil}

\section{LSE Law, Society and Economy Working Papers 6/2015} London School of Economics and Political Science

Law Department

\begin{abstract}
This paper can be downloaded without charge from LSE Law, Society and Economy Working Papers at: www.lse.ac.uk/collections/law/wps/wps.htm and the Social Sciences Research Network electronic library at: http://ssrn.com/abstract $=2575372$.

(C) Christos Hadjiemmanuil. Users may download and/or print one copy to facilitate their private study or for non-commercial research. Users may not engage in further distribution of this material or use it for any profit-making activities or any other form of commercial gain.
\end{abstract}




\title{
Bank Resolution Financing in the Banking Union
}

\author{
Christos Hadjiemmanuil *
}

\begin{abstract}
In early 2012, the Spanish state came under strong market pressure due to its engagement in round after round of large-scale bank bailouts. The country's joint sovereignbank crisis shed new light on the nature of the euro area's crisis. European decision-makers were forced to openly recognize the non-fiscal - that is, the banking and monetary - causes of sovereign distress and to accept the need for drastic policy solutions. The policy shift soon took concrete form with the launch of the Banking Union project in June 2012. The principal intention was to break the bank-sovereign link and to relieve the euro area's weaker economies from the almost impossible burden of having to finance bank bailouts out of national fiscal resources. The mutualization of bailout costs through a common 'fiscal backstop' was, in other words, the key objective of the Banking Union as originally conceived. Subsequent policy choices, however, have marked a relaxation, if not partial abandonment, of this objective. The policy approach eventually adopted with regard to resolution financing in the context of the Banking Union's Single Resolution Mechanism (SRM) is based on the burden-sharing norms of the Bank Recovery and Resolution Directive (BRRD), the instrument harmonizing bank resolution regimes across the EU. This guarantees the legal consistency of resolution frameworks within and outside the euro area. It is less certain, whether the chosen approach can insulate national state finances from the costs of bank bailouts and/or ensure the full equalization of the financial conditions for bank resolution everywhere in the euro area. The sufficiency of the planned common financial instruments is a particular concern.
\end{abstract}

\footnotetext{
* Visiting Professor at the Department of Law, London School of Economics; and Professor of International and European Monetary and Financial Institutions at the University of Piraeus. This essay has been prepared as a contribution to Jens-Hinrich Binder and Dalvinder Singh (eds), Bank Resolution: The European Perspective (Oxford: Oxford University Press, forthcoming 2015).
} 


\section{INTRODUCTION}

The Global Financial Crisis of 2007-09 triggered in Europe three overlapping phases of economic distress (section 1). At first, just like in the US, the troubles centred on the banking sector, spreading from there to the real economy. The fiscal implications were also significant for almost all member states. The need to bail out failed banks, support the continuing operation of the credit mechanism and provide countercyclical relief to the ailing economy, by means of both the automatic fiscal stabilizers and discretionary budgetary expansion, led to very high budgetary deficits for 2008 and 2009. Still, in its early phase the crisis was perceived as essentially global and bank-based, not fiscal. So were the policy responses. The crisis brought out into the open blind spots and design flaws in the pre-crisis framework of banking regulation (including bank crisis management). For their correction, extensive banking reforms were undertaken at the national and Union levels. To a large extent, the reforms reflected a broad regulatory agenda adopted globally under the auspices of the G20. They also included the introduction of a special resolution regime for failed banks. Originally adopted by leading member states such as the UK and Germany, the new approach to bank resolution was subsequently accepted by the whole Union, in the form of the harmonized European framework of the Bank Recovery and Resolution Directive ('BRRD'). ${ }^{1}$

In the meantime, however, a second wave of crisis engulfed in quick succession three countries in the periphery of the euro area (Greece, Portugal, and Ireland). The proximate cause was the inability of those state's governments to maintain their access to sovereign debt markets. Initially, their predicament was attributed to bad fiscal management and/or profligacy - a country-specific failure of governance. The European response involved the creation of special financial assistance mechanisms for the countries of the euro area, as well as a comprehensive revision of the EMU's economic governance arrangements, with a view to establishing fiscal discipline at the national level and ensuring the early correction of macroeconomic imbalances.

Nonetheless, by early 2012, with Spain coming under increasing market pressure, the euro area's troubles morphed into a joint sovereign-bank crisis. The Spanish predicament shed new light on the fundamental aetiology of the region's problems. It revealed the extent to which the supposedly idiosyncratic governance failures of the peripheral countries were structurally linked to the overall institutional set-up and operation of the euro area. The monetary and financial conditions prevailing in the region from the advent of the single currency in 1999

\footnotetext{
${ }^{1}$ Directive 2014/59/EU of the European Parliament and of the Council of 15 May 2014 establishing a framework for the recovery and resolution of credit institutions and investment firms and amending Council Directive 82/891/EEC, and Directives 2001/24/EC, 2002/47/EC, 2004/25/EC, 2005/56/EC, 2007/36/EC, 2011/35/EU, 2012/30/EU and 2013/36/EU, and Regulations (EU) No. 1093/2010 and (EU) No. 648/2012 of the European Parliament and of the Council, OJ 2014 No. L173/190.
} 
to the Global Financial Crisis a decade later had contributed, imperceptibly but fatefully, to the aggravation of macroeconomic divergences between the centre and the periphery. Through a distorted credit allocation mechanism, the interlinked banking systems of the single currency area (now based on a highly integrated wholesale market) fuelled major disequilibria in the pre-crisis years. The banks financed amply and cheaply the rapid growth in public and private consumption in the economies of the periphery. Rather than reflecting permanent gains in productive capacity and improvements in competitiveness, the debtfuelled growth in incomes and consumption was driven by inflows of liquidity from abroad, which eventually turned into a primary cause of high relative inflation and loss of competitiveness (always compared to the countries of the euro area's centre, out of whose trading surpluses and savings the periphery's debts were financed). Following the eruption of the Global Financial Crisis, the arrangements of the monetary union interacted in perverse ways with the EU's pre-existing single market framework. Crucially, the latter allocated the responsibility, not only for the ongoing supervision, but also for the resolution of credit institutions to the home countries. The consequences were dire, for both the states and the banking systems of the euro area's periphery. The region was plunged into an unprecedented crisis of confidence, which placed in question the very survival of the single currency and, by extension, of the European project as a whole.

As a result of the Spanish episode, European decision-makers were forced to openly recognize the non-fiscal - namely, banking and monetary - causes of sovereign distress. This recognition made imperative a substantial and drastic shift in the European policy stance. The Banking Union project was thus launched in June 2012 as a direct response to the euro area's crisis. The immediate intention was to relieve the euro area's weaker economies from the almost unbearable burden of having to finance domestic bank-rescue operations (or bailouts) with national fiscal resources. The prerequisite for a mutualization of bailout costs, however, was the centralization of the responsibility for banking supervision and resolution in the euro area, so as to preclude the externalization of the fiscal costs of regulatory failure by countries with lax regulatory regimes (section 2).

Through a more effective regulatory and supervisory control of European banks, the Banking Union's supervisory leg, namely, the ECB-based Single Supervisory Mechanism (SSM), is bound to contribute to the streamlining of the euro area's financial landscape. However, to break the vicious circle between sovereign-debt and banking troubles, thus ensuring the stabilization of the peripheral countries' situation and a full integration of the euro area's financial system (which during the crisis years largely decomposed into separate national systems, with divergent monetary and financial behaviour), the centralization of banking resolution arrangements is also necessary. The establishment of the Single Resolution Mechanism (SRM) is an important, but yet incomplete, step in this direction (section 3). To be effective, it must be supported by credible and uniform arrangements for the financing of resolution actions. This is a key 
component of the future resolution regime, with major ramifications for its capacity to equalize the conditions of operation and competition across banks and national banking markets (section 4). The policy solutions finally adopted in connection to the financing of resolution within the SRM are largely based on the norms of the BRRD (section 5). This guarantees the legal consistency of resolution frameworks across the EU. It is less certain, however, whether they also ensure the effectiveness and uniformity of resolution actions within the euro area's Banking Union (sections 6-7).

\section{PERMUTATIONS OF THE FINANCIAL CRISIS}

In Europe, and in particular in the euro area, the Global Financial Crisis activated not a single shock, but a set of consecutive - and, in our view, interrelated - crises. Each crisis (or, depending on how one sees it, each successive phase of the underlying, more general disease) was marked by distinctive symptoms. Due to this, each permutation provided the basis for distinct, and partially inconsistent, narratives and interpretations of what went wrong, and engendered diverse policy responses.

\section{FIRST PHASE, 2008-09: A REGIONAL EXPRESSION OF THE GLOBAL FINANCIAL CRISIS}

The first phase, lasting roughly from late 2008 to the end of 2009, had global dimensions (thus affecting all member states simultaneously and in the same sense), unmistakably financial aetiology and primarily financial symptoms. It was a systemic banking crisis of gigantic proportions; and it was immediately interpreted as proof that the global financial system, including its European component, was plagued by deep-seated problems and required urgent and extensive repair. The policy response encompassed the wide-ranging re-regulatory initiatives. The insistence on the need for SRRs was a central element of this global wave of financial re-regulation.

At the EU level, in view of the lack of prior steps in this direction, the sudden incorporation of SRRs in the Commission's legislative programme following the crisis marks a substantial turn in the evolution of European banking policy. But this is not the end of the story. Between the first tentative proposals for a European framework for bank crisis management in 2010 and the BRRD's final adoption in 2014, the European financial, economic and political landscape had changed dramatically. The draft BRRD was conceived as a rather typical harmonizing measure: it would set common parameters in relation to the resolution of failed banks, but would still depend for its practical application on national actors, namely, the various resolution authorities designated by the 
member states. More generally, in the BRRD's initial setting, the national responsibility for crisis management was not called into question. Just as the incorporation in European law of Basel III was not supposed to affect the allocation of the responsibility for front-line supervision to the member states' national competent authorities, the original intention was that the responsibilities for bank resolution and, where necessary, rescue operations would remain strictly national. Bank restructuring would be supported by exclusively national financial resources, namely, funds raised from the domestic banking sector in the form of pre-funded DGSs and resolution funds and, as a final backstop, national fiscal resources. No specific tools were provided for to deal with the collapse of large cross-border banks, with the exception of coordination through colleges of supervisory and resolution authorities. The possibility of cross-national financial assistance, especially in the form of fiscal transfers, for the purpose of bailing out failed banks was not entertained. And the role of supranational institutions in bank resolution was essentially confined to the responsibility of the Commission's Directorate-General for Competition for the prior approval of restructuring plans. In this allocation of burdens, the predicament of governments within the euro area which, faced with a banking crisis of systemic proportions, lack the fiscal space for raising the amounts required for stabilization was perceived as a primarily fiscal problem. As such, situations of this type would justify, at most, the provision of collective financial assistance to the relevant government through the euro area's collective country-rescue mechanisms, which were created starting in 2010 (EFSF/ESM). ${ }^{2}$ This was, indeed, what happened in the case of Ireland in November 2010 and of Spain in June 2012.

Of course, the regulatory reforms did not obviate the need for immediate financial interventions, seeking to counteract the economic downturn and, in particular, to provide relief to the banking sector. In terms of practical crisis management, Europe's governmental response relied primarily on national actions, which combined expansionary fiscal measures with the provision of massive support facilities in favour of the ailing domestic banking systems. Significantly, however, the measures adopted at the time did not entail a concerted and convincing cleansing of banks' balance sheets, through the removal of bad loans from their portfolios. National supervisory authorities were often reluctant to press their domestic banks to recognize in full their potential losses from nonperforming or doubtful loans. This contributed to the perpetuation of a climate of uncertainty, marked by market reservations regarding the true state of many significant banks.

Especially in the euro area, credit intermediation remained inadequate, as attested by a flight to safe assets, weak interbank lending and the hoarding of liquid reserves. Even the ECB's measures of monetary and credit easing ${ }^{3}$ proved

\footnotetext{
2 See below, n. 114-116 and accompanying text.

${ }^{3}$ In recent years, the ECB has utilized both conventional and unconventional tools in its attempt to support demand and provide liquidity to the banking sector. Not only has it maintained its key policy rate (main refinancing operation rate) at record low levels, but has also engaged in extraordinary long-term
} 
ineffectual, with recipient banks often retaining the money lent by the ECB liquid form in central bank deposit accounts as a safeguard or, what was worse, using it to the purchase of public debt instruments issued by their home country . And in countries in the region's periphery non-performing loans continued to pile rapidly in banks' portfolios. ${ }^{4}$

\section{SECOND PHASE, 2010-11: THE EURO AREA'S ‘SOVEREIGN DEBT’ CRISES}

While in other parts of the world the banking markets gradually returned to normality, in Europe the financial and economic recovery was hesitant, or worse. Moreover, the original crisis soon mutated into further economic and financial troubles, which hit with particular force the euro area, eventually placing in doubt the very survival of its single currency. The causes were apparently unrelated to the financial sector (or, for that matter, to the euro area's monetary arrangements). Indeed, this second phase took the form of a series of sovereign debt crises, which engulfed one by one the weaker, and allegedly less disciplined fiscally, economies in the euro area's periphery. Between late 2009 and early 2012, the sustainability of the public finances, first of Greece, and then of Portugal, Ireland, Cyprus, and even Spain, attracted in succession the strong and unforgiving scrutiny of the international capital markets. As a result, these countries either found themselves effectively cut off from the international capital markets or faced exceedingly high borrowing costs (expressed as rapidly rising interest-rate spreads over the rate charged on German sovereign debt issues, eventually rendering unsustainable the peripheral countries' cost of refinancing). The problems of the banking sector were thus eclipsed by a new, more pressing concern. In terms of immediate policy reactions, the situation was addressed through the provision to the countries affected by refinancing problems of large-scale emergency financial assistance; this came from their euro area partners and the IMF in the form of unprecedented financial assistance programmes, involving large-scale lending at attractive rates, subject to tough conditionality. In the Greek case such assistance was initially provided ad hoc, but the bailout system was soon regularized through the creation, first of a temporary collective mechanism, the European Financial Stabilization Fund (EFSF), 5 and then of a permanent mechanism, the European Stability Mechanism (ESM). ${ }^{6}$ Both were formed outside the framework of the Union,

refinancing operations (LTROs), including two operations of very long-term duration (36-month maturities), which provided ample liquidity to the banking system at low rates.

${ }^{4}$ See, e.g., OECD, 'OECD Economic Surveys: Euro Area' (April 2014), p. 18.

${ }^{5}$ EFSF Framework Agreement (7 June 2010), as amended.

${ }^{6}$ Treaty Establishing the European Stability Mechanism (ESM) (2 February 2012), as amended. 
although an amendment to the TFEU now ensures their recognition by, and compatibility with, the EU Treaty system. ${ }^{7}$

Initially, many observers attributed the crises in the euro area's peripheral countries almost exclusively to idiosyncratic domestic policy errors - especially the national governments' disregard for financial constraints ('fiscal irresponsibility') and a refusal to comply with European standards on public finances. If there was a collective European fault, this was thought to consist in the lax enforcement by the Econfin/Eurogroup of the Treaty provisions prohibiting excessive deficits and establishing a special enforcement procedure ('excessive deficit procedure' or 'EDP') ${ }^{8}$ and the related, but more detailed norms of the so-called Stability and Growth Pact ('SGP'). ${ }^{9}$ Later on, as the crisis came to hit countries with solid fiscal performance and a blameless record of compliance with the EDP, such as Ireland and Spain, the interpretations gradually and almost imperceptibly shifted towards recognizing the significance of broader macroeconomic imbalances between the countries of the centre of the euro area and those of the periphery. Such imbalances had built up in the decade since the adoption of the single currency, eroding the competitiveness of the periphery. Despite the recognition of this factor, however, the dominant interpretation amongst European policy-makers continued to place the blame on the 'policy mistakes' of the peripheral countries and to emphasize the need for fiscal discipline under all circumstances.

As a result, the correction of the underlying situation was pursued to a large extent on a country-by-country basis. Each of the troubled countries was called to follow a programme of fiscal retrenchment and far-reaching structural adjustment measures. Depending on the country-specific circumstances, the latter were intended to liberalize the domestic economy, restore its international competitiveness or overhaul the national financial system. In return, the rest of the euro area, led by Germany, offered (somewhat reluctantly) to provide large-scale bridge financing, as necessary for keeping thing running. It was taken for granted that any assistance should be contingent on strict and unforgiving policy conditionality. The notion that lender countries might need to make converse macroeconomic adjustments (for instance, by relaxing their own fiscal policy stance) was dismissed out of hand. Equally, intermittent proposals for joint debt issuance were ignored.

\footnotetext{
7 TFEU, art. 136(3), inserted in the Treaty in pursuance of the European Council Decision 2011/199/EU of 25 March 2011, OJ 2001 L91/1; and The compatibility of the ESM with EU law was confirmed by the CJEU in Case C-370/12, Pringle, judgment of 27 November 2012, OJ 2013 No. C26/15.

8 TFEU, art. 126; and Protocol (No. 12) on the Excessive Deficit Procedure.

9 The SGP was originally based on the Resolution of the European Council of 17 June 1997 on the Stability and Growth Pact, OJ 1997 No. C236/1. The original operative rules were revised in 2005, to ensure greater discretion and flexibility (and, effectively, greater laxity) in their application. Council regulation (EC) No. 1466/97 of 7 July 1997 on the strengthening of the surveillance of budgetary positions and the surveillance and coordination of economic policies, OJ 1997 L209/1, as amended by Council Regulation (EC) No. 1055/2005, OJ 2005 No. L 174/1; and Council regulation (EC) No. 1467/97 of 7 July 1997 on speeding up and clarifying the implementation of the excessive deficit procedure, OJ 2005 No. L209/6, as amended by Council Regulation (EC) No. 1056/2005, OJ 2005 No. L $1741 / 5$.
} 
Over and above the country-specific adjustment programmes, the more general and longer-term policy response focused at this stage on the 'reinforcement' on a permanent and highly institutionalized footing of the euro area's economic governance system. The relevant reform programme, outlined in pronouncements made by the Commission as early as May $2010^{10}$ and turned into binding legal texts in the following years, ${ }^{11}$ was directed towards strengthening to the maximum extent possible the mechanisms for preventative and corrective enforcement of the rules on the avoidance of fiscal deficits, including by increasing the automaticity of their application. ${ }^{12}$ These rules were now supplemented with further enforcement mechanisms for the avoidance and 'correction' of macroeconomic imbalances. ${ }^{13}$ The latter are intended to compel countries facing loss of competitiveness and growing trading deficits to adopt early on strict adjustment policies.

\section{THIRD PHASE, 2012: THE BANK-SOVEREIGN NEXUS}

The first round of country bailouts in 2010 (covering Greece, Portugal, and Ireland) offered a rather short respite. The political cacophony which characterized the opening of discussions on the establishment of the ESM as the

\footnotetext{
${ }^{10}$ European Commission, Communication on 'Reinforcing Economic Policy Coordination', COM(2010) 250 final (12 May 2005); and Communication on 'Enhancing economic policy Coordination for Stability, Growth and Jobs - Tools for Stronger EU Economic Governance' COM(2010) 367 final (30 June 2010).

${ }^{11}$ The reform of the economic governance framework took the form two legislative packages, the so 'sixpack' of 2011 and the 'two-pack' of 2013. These included: Regulation (EU) No.1173/2011 of the European Parliament and of the Council of 16 November 2011 on the effective enforcement of budgetary surveillance in the euro area, OJ 2011 No. L306/1; Regulation (EU) No. 1174/2011 of the European Parliament and of the Council of 16 November 2011 on enforcement measures to correct excessive macroeconomic imbalances in the euro area, OJ 2011 No. L306/8; Regulation (EU) No. 1175/2011 of the European Parliament and of the Council of 16 November 2011 amending Council Regulation (EC) No. 1466/97 on the strengthening of the surveillance of budgetary positions and the surveillance and coordination of economic policies, OJ 2011 No. L306/12; Regulation (EU) No. 1176/2011 of the European Parliament and of the Council of 16 November 2011 on the prevention and correction of macroeconomic imbalances, OJ 2011 No. L306/25; Regulation (EU) No. 1177/2011 of 8 November 2011 amending Regulation (EC) No. 1467/97 on speeding up and clarifying the implementation of the excessive deficit procedure, OJ 2011 No. L306/33; Directive 2011/85/EU of the Council of 8 November 2011 on the requirements for budgetary frameworks of the Member States, OJ 2011 No. L306/41; Regulation No. 472/2013 of the European Parliament and of the Council of 21 May 2013 on the strengthening of economic and budgetary surveillance of Member States in the euro area experiencing or threatened with serious difficulties with respect to their financial stability, OJ 2013 No. L140/1; and Regulation (EU) No. 473/2013 of the European Parliament and of the Council of 21 May 2013 on common provisions for monitoring and assessing draft budgetary plans and ensuring the correction of excessive deficit of the Member States in the euro area, OJ 2013 No. L140/11.

12 Beyond the two legislative packages ('six-pack' and 'two-pack') mentioned in the previous note, the attempts to entrench fiscal discipline included high-level political commitments and a separate treaty; 'Euro Plus Pact', Conclusions of the euro area summit of 11 March 2011, endorsed by the European Council in its own Conclusions of 25 March 2011, paras. 11-12 and Annex I; and Treaty on Stability, Coordination and Governance in the Economic and Monetary Union ('Fiscal Compact' or 'TSCG'), signed on 2 March 2012 by 25 of the then 27 EU member states (but not by the UK or the Czech Republic, nor by Croatia, which acceded subsequently to the Union, but not to the Fiscal Compact). ${ }^{13}$ See Regulation (EU) No. 1174/2011, OJ 2011 No. L306/8; and Regulation (EU) No. 1176/2011, OJ 2011 No. L306/25.
} 
euro area's permanent bailout mechanism in late 2010 was complemented by Germany's insistence that the 'orderly default' of euro area sovereigns (whereby losses would fall on their private creditors) should not be excluded in the future. ${ }^{14}$ The assumption that, despite the 'no bailout' clause in the TFEU, 15 the governments of the euro area would always provide de facto support to one another, thus turning the risk of sovereign default into a theoretical possibility - an assumption effectively validated by the Greek case earlier in the year - was now openly challenged. This contributed to a shift in risk perceptions and fuelled the uncertainty of the private sector. ${ }^{16}$

From July 2011 onwards, official plans for the restructuring of the Greek public debt in the form of a deep 'haircut' and drastic rescheduling of sovereign bond obligations to the private sector (the so-called 'Private Finance Initiative', or 'PSI') promised to inflict substantial losses on existing debtholders, both domestic and foreign. The significant exposure of many large and medium-sized banks to the sovereign debts of Greece and other troubled countries intensified the markets' doubts about their solvency. This factor, in combination with continuing high levels of leverage and, above all, rapidly growing fears that the euro area's currency union might unravel, with one or more of its member countries exiting, seriously disrupted the interbank market. Accessing liquidity became significantly more expensive and difficult, especially for banks in the euro area's peripheral economies. In the early months of 2012, the perverse dynamics of the latter (whereby the sovereigns' fiscal problems dovetailed with the considerable weakness of domestic banking systems, in a feedback mechanism) led to a major rekindling of the crisis, which thus entered into its third distinct phase.

This started from Spain, the EU's fifth largest economy. As the country had a stellar record of compliance with the SGP in the pre-crisis years, it would be totally implausible to attribute its woes to fiscal profligacy. Instead, the root of the problem lied in the Spanish government's flawed attempt to recapitalize the banking sector during the first phase of the crisis, back in 2010. At the time, the authorities had not insisted on a full recognition of the banking sector's bad asset problems; moreover, the recapitalizations had been carried out on terms that did not secure the permanence of the capital injections. The key problem was Bankia, the country's fourth largest bank, which had been created as recently as December 2010, through the consolidation of the operations of several ailing savings banks (cajas de ahorros). Instead of constituting the hoped-for solution to their distress, Bankia was now itself in need of a massive bailout. Due to the evident and pressing need for the state to engage in a second round of large-scale bank

\footnotetext{
${ }^{14}$ The notion was first aired by the German leadership on 4 May 2010; Tony Czuczka, 'Merkel's Coalition Calls for EU "Orderly" Defaults (Update1)', Bloomberg.com, http:/ $/$ www.bloomberg.com/apps/news?pid=newsarchive\&sid=aQdqR8poZMoo\&pos=9. Six months later, it had gained sufficient clout to be incorporated in the official Eurogroup policy; 'Statement by the Eurogroup' on the ESM, 28 November 2010.

15 TFEU, art. 125.

${ }^{16}$ Dauville, 28 Nov conclusions, December European Council.
} 
recapitalizations, by early 2012 the government was rapidly losing its access to the capital markets.

The escalation of the Spanish troubles brought to everybody's attention the perverse loop between weak banks and fiscally weak sovereigns. Early in the crisis, the Governor of the Bank of England Mervyn King had observed that 'global banks are global in life but national in death'. ${ }^{17}$ It had now become patently obvious that this applied with a vengeance to the banks of the euro area. In the pre-crisis period, euro area banks had taken full advantage of their European freedoms of movement and had exploited eagerly the opportunities offered by the newly unified euro money market to access ample amounts overseas liquidity. As a result of the crisis, however, crossborder liquidity lines had been disrupted, thus putting extreme pressure on banks in the periphery and, through them, on their domestic economies, whose contraction was aggravated by the paralysis of the credit provision mechanism; this fed back into the situation of the banks themselves, amplifying the deterioration of their assets. Faced with impending insolvency, the banks had turned to their national governments for support. With the responsibility for bank resolution falling solely to the home country (or, following a dissolution of a cross-border group, being split between the countries of operation according to the geographical break down of operations), the national taxpayers were thus called to shoulder the full cost of recapitalization. Whenever the home country was not large enough, or sufficiently rich, to bear the costs, matters were brought to a deadlock. In this respect, the case of Spain was not different from that of Ireland, which preceded it, or that of Cyprus, which followed. However, the size of the Spanish economy and the high probability of transmission of its crisis to another large member state, namely, Italy (and potentially even to France), set its case apart. Indeed, the 'Spanish' crisis created doubts, not only about the resilience of national economies, but about the viability of the single currency itself.

\section{THE BIRTH OF THE BANKING UNION: CRITICAL JUNCTURE AND RADICAL POLICY TURN}

The imminent threat of contagion led decision-makers at the European level to revise their frame of interpretation of the crisis and to reconsider the remedies. As its monetary-financial aetiology and ramifications emerged to light, the 'sovereign debt' crisis morphed into the 'euro' crisis. The obvious, but hitherto neglected, cross-border loops in the catastrophic financial dynamics were now acknowledged, and new goals and priorities were set in an effort to save the euro area. The long-

${ }^{17}$ Mervyn King, as quoted by Adair Turner, speech at the press conference for the presentation of the Turner Review (18 March 2009). 
debated, but extremely controversial and difficult to implement, idea of a fiscal union was brought up again by certain commentators. However, a different, but no less challenging prospect emerged from nowhere to gain traction almost immediately: that of a 'banking union'. ${ }^{18}$ Many academics, economic journalists and think tanks were already promoting the view that the crisis can only be tackled through concerted action on the fiscal and the banking fronts - in particular, through the centralization and federalization of the responsibility for banking supervision and restructuring in the European Union or, at least, in the euro area; but up till then their views had found limited resonance at the level of official European policy. Now, however, the Spanish quandary had brought the banksovereign dynamics to the centre of global and European policy-makers' attention. The conditions were propitious for policy innovations.

It was the IMF's Managing Director Christine Lagarde who, on 17 April 2012, first placed on the policy agenda the notion of a fully centralized legal and institutional framework for the euro area's banking system. In her view, moving to 'unified supervision, a single bank resolution authority with a common backstop, and a single deposit insurance fund' would constitute a necessary financialregulatory complement to the monetary union and provide a means for breaking the perverse bank-sovereign loop. ${ }^{19}$ An idea whose time had come, it only required a very short time to move from this initial act of semi-official endorsement to general and full acceptance as a basic pillar of European policy. On 25 April 2012 it was espoused by the new President of the ECB Mario Draghi, who declared his support for centralised banking supervision and resolution at European level. ${ }^{20}$

On 23 May 2012, in the course of an informal European Council dinner, Commission President Barroso apparently proposed a move in this direction, but

\footnotetext{
18 The term was probably coined by the policy expert Nicolas Véron a few months earlier; see Nicolas Véron, 'Europe Must Change Course on Banks', VoxEU.org, 22 December 2011, http://www.voxeu.org/article/europe-must-change-course-banks.

19 Christine Lagarde, 'Opening Remarks', IMF/CFP Policy Roundtable on the Future of Financial Regulation (17 April 2012): 'We must break the vicious cycle of banks hurting sovereigns and sovereigns hurting banks. This works both ways. Making banks stronger, including by restoring adequate capital levels, stop banks from hurting sovereigns through higher debt or contingent liabilities. And restoring confidence in sovereign debt helps banks, which are important holders of such debt and typically benefit from explicit or implicit guarantees from sovereigns. [...] In the euro zone, a single financial market cannot rely on legal and institutional frameworks that operate on an asymmetric national basis. To break the feedback loop between sovereigns and banks, we need more risk sharing across borders in the banking system. In the near term, a pan-euro area facility that has the capacity to take direct stakes in banks would help. Looking further ahead, monetary union needs to be supported by stronger financial integration which our analysis suggests be in the form of unified supervision, a single bank resolution authority with a common backstop, and a single deposit insurance fund.'

${ }^{20}$ Mario Draghi, 'Introductory Statement' before the Committee on Economic and Monetary Affairs of the European Parliament (25 April 2012): 'I see financial stability clearly as a common responsibly in a monetary union. During the crisis, we have observed strong negative spill-over effects across euro area countries and between the banking sector and its respective sovereign. National supervisors and Treasuries are also confronted with the well-known problem that during good times, large banks work as European institutions but in bad times fall on national shoulders. Ensuring a well-functioning EMU implies strengthening banking supervision and resolution at European level.'
} 
the decision was left for the body's regular June meeting. ${ }^{21}$ The concept of an 'integrated financial framework' was then fleshed out and identified as one of 'four essential building blocks' for the future EMU in the report entitled 'Towards a Genuine Economic and Monetary Union', which the Union's 'four presidents' (that is, the European Council's own President Van Rompuy, in collaboration with the Presidents of the Commission Barroso, of the Eurogroup Juncker and of the ECB Draghi) submitted jointly to the European Council. ${ }^{22}$ For the first time, the official European position appeared to recognize, albeit reluctantly, that the euro area's crisis is not confined to the fiscal plight of certain countries in the region, but is the product of a more complex pathology, the elements of which interact and reinforce one another.

On this basis, the European political leadership endorsed in principle the Banking Union project on 29 June 2012.23 In particular, the leaders of the euro area's member states now declared that 'it is imperative to break the vicious circle between banks and sovereigns'. For this purpose, they asked the Commission to 'present proposals on the basis of Article 127(6) [of the TFEU] for a single supervisory mechanism shortly' and the Council to 'consider these proposals as a matter of urgency by the end of 2012'.

Revealing the true intention behind this very tight schedule, they had this to add: 'When an effective single supervisory mechanism is established, involving the $\mathrm{ECB}$, for banks in the euro area the ESM could, following a regular decision have the possibility to recapitalize banks directly. ${ }^{24}$ In other words, the rapid move to a streamlined supranational supervisory system was necessary as a prerequisite for the mutualization of bank recapitalization efforts. The principle whereby the financial liability for rescue operations or bailouts must remain at the same governance level where supervision is exercised, so as to preclude an externalization of the effects of deficient supervisory performance, was kept alive on German insistence. Nonetheless, the agreement of the leaders was initially understood as a commitment that before the end of the year, and irrespectively of the envisaged supervisory mechanism' exact form, the ESM would be substituted to the fiscally vulnerable governments of the euro area's periphery as paymaster of any further bank recapitalization efforts. ${ }^{25}$

\footnotetext{
${ }^{21}$ See European Council press release, 'Remarks by President of the European Council Herman Van Rompuy Following the Informal Dinner of the Members of the European Council', EUCO 93/12 (24 May 2012), noting that '[c]olleagues expressed various opinions on issues such as eurobonds in a time perspective, more integrated banking supervision and resolution, and a common deposit insurance scheme' - without, however, mentioning specifically President Barroso.

22 The other three building blocks identified in the report were: an integrated budgetary framework; an integrated economic policy framework; and strengthened democratic legitimacy and accountability.

${ }_{23}$ Euro Area Summit statement, 29 June 2012; and European Council conclusions, 28-29 June 2012, paras. 4 and IV(a).

${ }^{24}$ Euro area summit, 29 June 2012.

25 See Nicolas Véron, 'Europe's Banking Union: Possible Next Steps on a Bumpy Path', post at the RealTime blog of the Peterson Institute for International Economics, 3 July 2012, http://blogs.piie.com/realtime/?p=3004.
} 
The endorsement in principle by the European Council of the Banking Union (as the new project came to be called almost immediately) was followed within weeks, first by an uncharacteristically strongly-worded commitment of the ECB President Mario Draghi 'to do whatever it takes to preserve the euro', 26 and then by the announcement by the ECB of the so-called 'outright monetary transactions' ('OMT') programme. ${ }^{27}$ The OMT allows, under certain conditions, the ECB to intervene in the secondary markets for the purpose of stabilizing the prices of a country's sovereign bonds, if this country comes under extraordinary and, in the ECB's view, unjustified market pressure. It should be noted in this context that, due to the interrelated banking and sovereign debt troubles, the supposedly single monetary area has effectively split into national segments, with dissimilar inflation trends, interest rates and credit market conditions. For instance, while the ECB's policy rate is the same for all countries and all banks in the euro area, the cost of credit differs significantly from country to country, so that borrowers (businesses and households) in the peripheral countries face much steeper conditions than those at the center. Since 2010, interest rates on new loans in Greece or Portugal are immensely higher than in Germany (at 5 to $7 \%$, as compared to 2 to 3\%); the situation in Italy or Spain is somewhat better, but the divergence is still substantial. ${ }^{28}$ Against this backdrop, the ECB considered that the possibility of intervention in sovereign bond markets with a view to quell unwarranted and asymmetrical attacks on particular countries would be necessary as a means of 'safeguarding an appropriate monetary policy transmission and the singleness of the monetary policy'. ${ }^{29}$ Regardless of the monetary implications, the combined effect of the announcement of the Banking Union and these moves by the ECB was enough to stem the turbulence, boost market confidence and precipitate a virtual spiral of declining yields for the bonds of the governments of the euro area's periphery. ${ }^{30}$

Soon, however, a number of lender countries had second thoughts about the use of the ESM in support of the recapitalization of banks whose failure could be attributed to so-called 'legacy assets', that is, to the crystallization of losses on transactions concluded prior to the move to a unified supervisory system. ${ }^{31}$ More generally, these countries had reservations about the mutualization of the costs of

\footnotetext{
26 Mario Draghi, speech at the Global Investment Conference (London, 26 July 2012): 'Within our mandate, the ECB is ready to do whatever it takes to preserve the euro. And believe me, it will be enough'.

27 The OMT programme was publicly announced, following its endorsement by the ECB's Governing Council, on 2 August 2012, although the technical framework was announced only a month later, on 6 September 2012; ECB press release, 'Technical Features of Outright Monetary Transactions' (6 September 2012).

28 OECD, 'Euro Area', above, n. 113, pp. 14 and 17.

29 The ECB's Governing Council reached its decision on the OMT programme over the Bundesbank's objections. The validity of the decision has been challenged before the German Constitutional Court (Bundesverfassungsgericht) and the CJEU; BVerfG, decision of 14 January 2014, 2 BvR 2728/13; and CJEU, Case C-62/14 (not yet decided, opinion of AG Cruz Villalón delivered on 14 January 2015).

30 As a result, up till now the OMT instrument has never been actually put into operation.

${ }^{31}$ Joint Statement of the Ministers of Finance of Germany, the Netherlands and Finland, 25 September 2012.
} 
bank bailouts. Their objections had two practical consequences: first, the legislative process for the enactment of the key Banking Union legislation took longer than originally intended; and second, the final decisions on the financial arrangements for banking resolution kept being postponed. As discussed in detail below, the latter issue remains partially unresolved.

\section{THE CONCEPT APPLIED}

Still, in the two years between the Banking Union's original endorsement by the European Council and the election of a new European Parliament and Commission in 2014, remarkable progress was achieved, with the enactment of framework legislation for all its major planks. By European standards, the legislative process was completed in a remarkably short time.

In applied terms, the Banking Union is a streamlined and highly centralized regime for the supervision and resolution of all banks in the euro area and beyond, based on a novel, complex institutional set-up. Although it reserves specific operational roles for national supervisors and resolution officials, for the truly critical decisions it relies on supranational decision-making, especially with regard to the largest and most important banking institutions. Its two-pronged institutional construction comprises a Single Supervisory Mechanism and a separate Single Resolution Mechanism. Both mechanisms will apply in their respective fields the relevant norms of the pan-European 'single rulebook'. ${ }^{32}$

\section{SINGLE SUPERVISORY MECHANISM (SSM)}

The SSM entails the creation of an integrated organizational framework for prudential supervision (but not of conduct-of-business and/or consumer-related regulation). ${ }^{33}$ It is founded on two legal instruments: a regulation on the

\footnotetext{
32 The single rulebook was not designed with specific reference to the challenges facing the monetary union. In fact, the expression clearly predates the Banking Union project; see above, n. 75 and accompanying text. Many of the legislative proposals covered by the term antedate even the second (sovereign-debt-related) phase of the crisis, and certainly did not anticipate the third, which eventually caused the move to a Banking Union. Nonetheless, the single rulebook was retrospectively identified as one of the three foundational elements of the Banking Union, alongside the SSM and the SRM. Of course, the single rulebook applies across the EU (as well as in the three other countries of the EEA, once the EEA Joint Committee amends the EEA Agreement for the purpose of extending the applicability of the relevant instruments to them); but specific differentiations between the euro area and other member states are possible on matters relating primarily to the operation of the monetary union and its economy, rather than the single market.

33 See Christos Vl. Gortsos, "The "Single Supervisory Mechanism": A Major Building Block towards a European Banking Union (The Full Europeanisation of the "Bank Safety Net")", ECEFIL Working Paper No 2013/8 (June 2013).
} 
organization and procedures of the SSM itself ('SSM Regulation'), ${ }^{34}$ establishing the ECB's role as the Banking Union's ultimate supervisory authority; and an accompanying instrument, which amended the legal framework of the European Banking Authority (EBA) for the purpose of ensuring a balance between the countries of the Banking Union and the non-participating member states in its decision-making procedures. ${ }^{35}$

It should be noted that, while participation in the Banking Union and its SSM is automatic for all euro area countries, other countries may also join on a voluntary basis. For this purpose, they must enter into a 'close cooperation' agreement with the ECB, so as to guarantee the ECB's legal capacity to perform its supervisory work in their territory and to commit these countries to make the ECB's supervisor decisions binding upon their national competent authorities. ${ }^{36}$ Such agreements can be ended either by the ECB or by the country involved. ${ }^{37}$ Accordingly, the participation of non-euro area member states in the Banking Union is neither seamless nor irreversible. Although certain countries have expressed an interest to join on this basis, up till now none has done so.

The new supervisory architecture is structured in two levels. The supervisory responsibility for the Banking Union's most significant banks is concentrated at the supranational level and entrusted to the ECB. ${ }^{38}$ Generally speaking, a bank is considered 'significant', if it is one of the three largest credit institutions in its home member state, if the volume of its assets is larger than $20 \%$ of the home member state's GDP, or if the volume of its assets is over $€ 30$ billion. ${ }^{39}$ On these criteria, 120 banks across the euro area have been classified as 'significant'. 40 Following a comprehensive assessment of their financial condition, to ensure that the transition would not entail the grandfathering of previously unidentified legacy problems into the new regime, ${ }^{41}$ the responsibility for the direct supervision of

34 Council Regulation (EU) No. 1024/2013 of 15 October 2013 conferring specific tasks on the European Central Bank concerning policies relating to the prudential supervision of credit institutions, OJ 2013 No. L287/63.

35 Regulation (EU) No. 1022/2013 of the European Parliament and of the Council of 22 October 2013 amending Regulation (EU) No. 1093/2010 establishing a European Supervisory Authority (European Banking Authority) as regards the conferral of specific tasks on the European Central Bank pursuant to Council Regulation (EU) No. 1024/2013, OJ 2013 No. L287/5.

${ }^{36}$ SSM Regulation, art. 7.

${ }^{37}$ SSM Regulation, art. 7(6), (8)-(9).

${ }^{38}$ For this reason, the SSM Regulation has not been enacted as an instrument of market harmonization based on the general provision of TFEU, art. 114, but on the narrow basis of the provision which allows the assignment to the ECB of 'specific tasks [...] concerning policies relating to the prudential supervision of credit institutions and other financial institutions with the exception of insurance undertakings'; TFEU, art. 127(6); and Statute of the ESCB, art. 25.2.

${ }^{39}$ SSM Regulation, art. 6(4).

${ }^{40}$ ECB, 'The List of Significant Supervised Entities and the List of Less Significant Institutions' (04 September 2014).

${ }^{41}$ Conducted between November 2013 and October 2014 in preparation for the assumption by the ECB of supervisory functions within the SSM, the comprehensive assessment was based on the SSM Regulation, art. 33.4. It covered all banks to be directly supervised by the ECB - that is, 130 banks in 18 countries, controlling between themselves around $82 \%$ of the euro area's total bank assets. The assessment had three elements: a supervisory risk assessment, covering key risks in banks' balance sheets, including liquidity, leverage, and funding; an asset quality review, focusing on a close scrutiny of all asset 
these banks passed from the competent authorities of the home countries to the ECB on 4 November 2014, at which point the SSM became fully operational.

The front-line supervision of less important banks remains in the hands of the national competent authorities; but the ECB is responsible for the authorization and vetting of the major shareholders of these institutions too, and it retains powers of intervention, which enable it to assume direct supervisory responsibility for any particular bank.

To preserve the integrity of monetary and supervisory decision-making and to safeguard the functional independence of monetary policy-making, within the ECB supervisory tasks are carried on separately from the monetary functions by a specialist bureaucracy. ${ }^{42}$ The overall responsibility for planning and execution belongs to a newly-formed internal body, the Supervisory Board, which is composed by a Chair, a Vice Chair, four representatives of the ECB who must not be involved with monetary-policy tasks, and one representative from each national competent authority. ${ }^{43}$ Decisions in the Supervisory Board are taken by simple majority of the members. ${ }^{44}$ As the ECB's statute reserves the ultimate decisionmaking power for the Governing Council, the Supervisory Board cannot take itself the final decisions relating to the authorization of credit institutions or the imposition of sanctions. Instead, the Supervisory Board prepares and submits full draft decisions which the Governing Council can adopt or reject, giving reasons in writing, but not amend; the draft decisions are deemed to have adopted, unless it objects within a specified period of time, which cannot exceed ten working days. ${ }^{45}$ In case of objection, the SSM Regulation provides for a referral of the matter to a Mediation Panel. 46

\section{Single Resolution Mechanism (SRM)}

The responsibility of the ECB extends to the adoption of appropriate measures, when a bank has crossed the triggers for early intervention. ${ }^{47}$ When, however, a bank is found to be failing, its resolution will in the future be carried out by the Banking Union's second mechanism, the SRM. ${ }^{48}$ The SRM includes common decision-making procedures for bank resolution, supported by common financial arrangements in the form of a Single Resolution Fund (SRF) (but not by common deposit guarantee arrangements, since the system of separate national DGSs

categories; and a stress test of banks' balance sheets as of 31 December 2013, which was intended to provide a forward-looking view of banks' shock-absorption capacity under stress. ECB press release, 'ECB Starts Comprehensive Assessment in Advance of Supervisory Role' (23 October 2013).

42 SSM Regulation, art. 25.

43 SSM Regulation, art. 26(1), (5).

44 SSM Regulation, art. 26(6).

45 SSM Regulation, art. 26(8).

46 SSM Regulation, art. 25(5).

47 BRRD, arts. 27-30; and SRM Regulation, art. 13.

48 For a concise description, see Commission memo, 'A Single Resolution Mechanism for the Banking Union - Frequently Asked Questions', MEMO/14/295 (15 April 2014). 
continues). The operation of the SRM is based on a regulation establishing a Single Resolution Board (SRB) as the central resolution authority and setting out the decision-making procedures for resolution ('SRM Regulation').49 A separate intergovernmental agreement ('IGA on the SRF'), ${ }^{50}$ reached outside the Treaty framework, regulates the pooling in the SRF of contributions raised from banks at the national level.

Unlike the SSM, the SRM is not yet operational. Certain provisions of the SRM Regulation are already effective, so as to enable the formation of the SRB and the commencement of the SRM's preparatory work (that is, resolution planning in relation to individual banks and banking groups); but the actual power to resolve banks will only pass to the SRM on 1 January $2016^{51}$ - always assuming that the IGA on the SRF will have entered into force by then..$^{52}$

The SRM will cover automatically all banks establish in the countries of the Banking Union, including non-euro area countries which have joined by way of a 'close cooperation' agreement. ${ }^{53}$ Within the SRM, the SRB will be directly responsible for resolution planning in relation to the banks which are supervised directly by the ECB, while the national resolution authorities will assist the SRB in this task and will also be primarily responsible for smaller banks. ${ }^{44}$ The main resolution decisions in relation to ECB-supervised banks, as well as to those domestically supervised institutions whose resolution necessitates the use of the SRF, will be taken by the SRB. ${ }^{55}$ But the actual execution of the resolution scheme is left to the national resolution authorities; the latter will apply the requisite measures in accordance to their domestic company and insolvency law. ${ }^{56}$ In all cases, the actions of the national resolution authorities will be subject to the SRB's powers of intervention. ${ }^{57}$

The SRB consists of a Chair, four permanent members, and representatives of the national resolution authorities of all participating countries, with

\footnotetext{
49 Regulation (EU) No. 806/2014 of the European Parliament and of the Council of 15 July 2014 establishing uniform rules and a uniform procedure for the resolution of credit institutions and certain investment firms in the framework of a Single Resolution Mechanism and a Single Resolution Fund and amending Regulation (EU) No. 1093/2010, OJ 2014 No. L225/1. Unlike the SSM Regulation, this one is adopted as a single-market measure on the basis of TFEU, art. 114. The appropriateness and sufficiency of this legal basis is questionable, especially in so far as the conferral of decision-making tasks to the SRB (a new body, whose operation is not provided for in the Treaties) is concerned; cf. ECJ, Case 9/56, Meroni [1957/1958] ECR 133.

50 Agreement on the transfer and mutualization of contributions to the Single Resolution Fund. The agreement was signed by 26 member states (that is, all except Sweden and the UK) on 21 May 2014. See also SRM Regulation, art. 1, third para.

51 SRM Regulation, art. 99(2)-(5)

52 The IGA on the SRF is intended to apply from 1 January 2016, simultaneously with the main provisions of the SRM Regulation; but, to come into effect, it requires ratification by countries representing $90 \%$ of the weighted vote of the member states participating in the Banking Union. As at end 2014, only one country (Latvia) had completed the ratification process.

${ }^{53}$ SRM Regulation, arts. 2 and 4.

54 SRM Regulation, arts. 5(1) and 7-9.

55 SRM Regulation, arts. 7(2)-(3), 16 and 18.

56 SRM Regulation, arts. 18(9) and 28-29.

${ }^{57}$ SRM Regulation, art. 28(2) and 31.
} 
representatives of the ECB and the Commission participating in its procedures as permanent observers. ${ }^{58}$ It must be noted, however, that the SRB considers individual cases either in a plenary session or in a truncated formation, the socalled 'executive session', which includes only the Chair, the four permanent members and those national representatives who represent countries where the bank under consideration has a presence (headquarters, branches and/or subsidiaries). ${ }^{59}$ Resolution decisions are taken in executive session, except when the resolution scheme provides for support by the SRF in excess of $€ 5$ billion or when the the net accumulated use of the Fund in the last consecutive 12 months has exceeded the threshold of $€ 5$ billion. ${ }^{60}$

The resolution procedure is complex, but exceptionally expeditious. ${ }^{61}$ In particular, upon notification from the ECB of a bank's actual or impending failure or on its own initiative, the SRB assesses the bank's condition and draws the resolution scheme, specifying the appropriate resolution tools and financing arrangements, including the extent to which the SRF may be used.62 To take effect, the resolution scheme proposed by the SRB requires the approval of the Commission or, when the Commission refers the matter to it, of the Council. ${ }^{63}$ In case of objection by either of them, the SRB must reconsider the situation and amend the resolution scheme in accordance with the reasons given for the objection. ${ }^{64}$ The various procedural steps must take place within very tight time limits, ensuring the completion of the whole procedure within no more than 32 hours - the length of the proverbial weekend. ${ }^{65}$

In the present text, it is not possible to delve into all aspects of the set-up and procedure of the SRM. However, the question of resolution financing must be addressed, given that financing considerations were paramount in the decision to move to a Banking Union. As we will see, the interaction of the BRRD's principal legal policy, which is to ensure that henceforth the taxpayer's part in the resolution burden-sharing will be confined to the bare minimum, with the political wrangling relating to the mutualization of resolution financing, has transformed subtly but profoundly the fundamental rationale of the Banking Union.

\footnotetext{
58 SRM Regulation, art. 43.

59 SRM Regulation, arts. 49 and 53.

60 SRM Regulation, arts. 50(1)(c)-(d) and 54(1)(b).

61 SRM Regulation, art. 18.

62 SRM Regulation, art. 18 (1), (6).

${ }^{63}$ SRM Regulation, art. 18(7).

${ }^{64}$ SRM Regulation, art. 18(7), sixth and seventh subparas.

65 SRM Regulation, art. 18(7).
} 


\section{THE NEED FOR A COMMON 'FISCAL BACKSTOP' AS RAISON D'ÊTRE OF THE MOVE TO A BANKING UNION}

The whole point of the Banking Union was to sever the perverse loop between bank failure and sovereign debt distress by mutualizing the fiscal costs of bank resolution. The establishment of a joint public funding mechanism with particularly deep pockets - a so-called common 'fiscal backstop' - for the whole euro area, was considered essential for this purpose. Such a mechanism could simultaneously relieve the budgetary pressure on the governments of the periphery and provide a way out of their local banking crises: the risk that an impaired banking system may require a publicly financed bailout would no longer dominate the assessment of a country's fiscal sustainability; at the same time, the credibility of bank restructuring efforts would be tremendously enhanced by the inclusion of supranational financing arrangements.

The centralized funding of recapitalizations would further imply an equalization of the bailout prospects for banks located anywhere in the euro area. This would eliminate an important source of national distinctiveness in the banking system. In the wake of the Lehman Brothers debacle, the euro area's governments had made a solemn collective promise to support the European banking system during 'the current exceptional circumstances', including by preventing the failure of banks in the region and ensuring their recapitalization with state funds, if necessary. ${ }^{66}$ The ensuing bank rescue programmes were undertaken by the national governments severally. However, not all governments were equally well placed to guarantee in a credible manner the survival of their domestic banks. The financial strength of the relevant member state thus came to dominate the market's assessments of relative bank riskiness. This was a key factor in the disruption of cross-border lending. It was aggravated by the behaviour of certain national banking authorities, which sought to ensure the national ringfencing of available liquidity by discouraging cross-border refinancing even between entities within the same banking group. The ensuing fragmentation along national lines of banking and monetary conditions (which, theoretically, should be completely unified in a monetary union) has since been a major drag on the recovery efforts of the peripheral economies. In view of the above, the mutualization of the fiscal responsibility for bank rescue operations would be a major step towards the reversal of the situation, the convergence of monetary conditions and the reintegration of the credit allocation mechanism, thus contributing to the attainment of the objectives of both the Single Market and the EMU.

Such were the considerations which drove the European leaders on 29 June 2012 to explicitly affirm the need to break the 'vicious circle between banks and sovereigns', adding that '[w] hen an effective single supervisory mechanism is

\footnotetext{
${ }^{66}$ Summit of the Euro Area Countries, 'Declaration on a Concerted European Action Plan of the Euro Area Countries' (12 October 2008).
} 
established, involving the ECB, for banks in the euro area the ESM could, following a regular decision, have the possibility to recapitalize banks directly'. ${ }^{67}$ At this point it is worth repeating that the ESM, the euro area's intergovernmental financial assistance mechanism, was created specifically as a tool for the management of sovereign debt crises, not financial ones; thus, in its original configuration, it could only support a banking-sector-orientated programme indirectly, ${ }^{68}$ by extending a loan to the relevant national government, which could then apply the borrowed funds on its own account to the necessary bank recapitalization actions ('indirect bank recapitalization' by the ESM). ${ }^{69}$ When assistance is provided in this manner, however, the borrowed funds increase immediately the recipient country's public debt. In contrast, the direct recapitalization of banks by the ESM would leave a country's fiscal situation unaffected. Expanding the ESM's role in this direction, then, was the key premise of the original decision to move to a Banking Union. The leaders effectively sanctioned the development of a supranational financing instrument -the hopedfor common fiscal backstop- for the recapitalization of weak banks, thus alleviating the pressure on national budgets. The decision to centralize the banking supervisory function was a by-product of this development. Without supranational supervision, the existence of an external (supranational) financial guarantee would generate moral hazard: national governments and competent authorities would now be more likely to adopt a lenient supervisory stance, since this would help the national banking sector gain market share in the internal market, while the downside risk of having to pay for a bailout would be shared with the other economies. For this reason, the responsibility for supervision should be moved to the same level, where the public safety-net would now be located.

In the course of constructing the Banking Union, however, something remarkable happened: the centralization of supervision was carried out decisively; but in the meantime its actual premise (that is, the centralization of the fiscal backstop for bank resolution) was all but abandoned. ${ }^{70}$

Almost from the start, the negotiations on the set-up of the Banking Union's two mechanisms were marked by divergent interpretations of the final objectives.

\footnotetext{
${ }^{67}$ Euro Area Summit statement, 29 June 2012. See also European Council conclusions, 28-29 June 2012, para. IV(a), 'welcoming' the statement of the Euro Area Summit; and European Council conclusions, 1314 December 2012, para. 10.

${ }^{68}$ In particular, on the basis of the ESM Treaty, art. 15; and ESM, 'Guideline on Financial Assistance for the Recapitalisation of Financial Institutions'.

${ }^{69}$ This is how the EFSF/ESM financed Spain's bank recapitalization efforts in 2012. As agreed in July 2012, the programme was for an 18-month period and involved financing of up to $€ 100$ billion, but in the event Spain only drew some $€ 41.4$ billion. See Master Financial Assistance Facility Agreement between European Financial Stability Facility, Kingdom of Spain as Beneficiary Member State, Fondo de Reestructuración Ordenada Bancaria as Guarantor and the Bank of Spain (24 July 2012). The EFSF facility was assumed by the ESM on 28 November 2012.

70 Silvia Merler, 'Comfortably Numb: ESM Direct Recapitalization - Too Late to Solve the Current Crisis, Too Little to Deter Future Crises', Bruegel.org, 24th June 2014, http://www.bruegel.org/nc/blog/detail/article/1369-comfortably-numb-esm-direct-recapitalization.
} 
At the height of the euro area's crisis, Germany and its closest allies in the debate, the Netherlands and Finland, had been forced to acquiesce in principle to a common fiscal backstop. Subsequently, however, they took advantage of the crisis' relative abatement to qualify the original decision. For them, the retention of an effective national veto over the use of financial resources was a key priority. To avoid a loss of control, they resisted strongly the most robust forms of centralization of bank resolution, and even supervision. In particular, they drew the line on the issue of so-called 'legacy assets': who should bear the costs of recapitalization for banks who fail as a result of losses on pre-existing bad assets? The three countries were adamant that the ESM should never take direct responsibility in cases of this type, ${ }^{71}$ since this would amount to an ex post facto mutualization of the costs from past national supervisory failures. If so, however, the availability of the common fiscal backstop in the foreseeable future -and, accordingly, its usefulness as a way out of the ongoing crisis- would be practically nil. Their insistence on comprehensive supervisory stock-taking and cleaning up prior to the establishment of the common fiscal backstop was essentially the reverse of what the Commission, the ECB and the countries of the euro area's periphery were trying to achieve in the short run. Equally, with regard to the longrun steady state, the need for national approvals as a precondition for the direct recapitalization of banks by the ESM undermines the basic rationale of the original scheme, which was to equalize the conditions of operation of banking systems across the euro area by providing a permanent and convincing (both in terms of size and conditions of activation) fiscal backstop, whose intervention would not depend on political wrangling or national considerations.

Under the pressure of the most powerful lender countries, the negotiations soon led to a reconceptualization of the Banking Union project. Indeed, the member states and the Union institutions managed to converge on the institutional and procedural organization of the Banking Union's two mechanisms in record time; but agreement was feasible only because key questions relating to the SRM's promised common fiscal backstop were left open, whereas the legislation included prescriptive norms specifically aimed at ensuring that (a) the use of public funds in bank resolution would be avoided under all but the most pressing circumstances, and even then kept to a minimum, through an application of a strict bail-in approach, and (b) the primary fiscal responsibility for resolution would remain at the national level, with the mutualized fiscal backstop serving as an absolutely last resort.

Specifically, the possibility of direct recapitalization of banks by the ESM was a common theme of the initial European Council pronouncements on the Banking Union. ${ }^{72}$ It soon became apparent, however, that in the future the recapitalization of banks with fiscal resources - the primary form of state

\footnotetext{
71 'Joint Statement of the Ministers of Finance of Germany, the Netherlands and Finland' (25 September 2012).

72 Euro Area Summit statement, 29 June 2012; European Council conclusions, 18-19 October 2012, para. 12; European Council conclusions, 13-14 December 2012, para. 10-11.
} 
intervention during the Global Financial Crisis - would be the exception rather than the rule. A critical step in this direction was taken in June 2013, with the conclusion of the negotiations on the Council's general approach to the draft BRRD, ${ }^{73}$ which was paralleled by an agreement in the Eurogroup on the main features of the ESM's future 'direct recapitalization instrument' ('DRI'). ${ }^{74}$ The financial framework for resolution was further clarified in December 2013, when a final, successful round of inter-institutional negotiations on the relevant provisions of the BRRD and the DGSD ${ }^{75}$ was immediately followed by a compromise between member states in the Ecofin on the draft SRM Regulation and the basic parameters of the Single Resolution Fund. ${ }^{76}$ The detailed provisions of operation of the latter were specified a few months later, when the IGA on the SRF was signed. This coincided with the final enactment of the key legislative texts on bank resolution (SRM Regulation, BRRD, DGSD), which further entrenched the new policies. The technical picture was completed in May-June 2014, with the drafting of internal ESM rules for the operation of the DRI, ${ }^{77}$ which the Eurogroup endorsed by way of a 'political understanding' on the matter. ${ }^{78}$ This paved the way for the DRI's final inclusion in the toolkit of ESM financial assistance instruments on 8 December 2014 (a month after the full activation of the SSM). ${ }^{79}$

The policy choices made on these occasions locked in a requirement of extensive bail-in of private stakeholders and the avoidance of public assistance in all but the most extreme circumstances as principal characteristics of the European approach to bank resolution. To ensure a uniform resolution regime across the wider internal market, care was taken to ensure that the operation of the Banking Union's SRM will be compatible with the pan-European framework established by the BRRD. The principles and rules in the latter also apply to the

\footnotetext{
${ }^{73}$ Ecofin conclusions, 27 June 2013.

74 'ESM Direct Bank Recapitalisation Instrument - Main Features of the Operational Framework and Way Forward' (20 June 2013).

75 Lithuanian Presidency press release, 'Lithuanian Presidency Reaches Political Agreement on Bank Bailout Rules' (12 December 2013). The release emphasizes that '[the BRRD] is dedicated to save tax payers money. It was agreed to have strict bail-in rules, which would ensure less moral hazard in the financial system and protection of tax payers' interests in financial crisis situations.' See now BRRD, rec. (103), third sentence, and (109), first sentence.

${ }^{76}$ Ecofin conclusions, 18 December 2013; and 'Statement of Eurogroup and ECOFIN Ministers on the SRM Backstop' (18 December 2013). See also European Council conclusions, 19-20 December 2013, para 29.

${ }^{77}$ ESM, 'Draft Guideline on Financial Assistance for the Direct Recapitalisation of Institutions' (23 May 2014).

78 Eurogroup President statement, 'ESM Direct Recapitalisation Instrument' (10 June 2014); and ESM, 'FAQ on the Preliminary Agreement on the Future ESM Direct Bank Recapitalisation Instrument' (10 June 2014).

${ }^{79}$ ESM Board of Governors Resolution No. 4 of 8 December 2014 (SG/BoG/2014/05/04). While the five original financing instruments of the ESM are enumerated in the ESM Treaty, art. 14-18, this was introduced by way of a unanimous resolution of the ESM Board of Governors (that is, the finance ministers of the countries of the euro area, chaired by the Eurogroup President) based on the reserve provision of art. 19.
} 
SRM - albeit subject to certain modifications, necessitated by its supranational nature, specific structure and economic context. ${ }^{80}$

\section{THE BRRD'S BURDEN-SHARING CASCADE AND ITS IMPACT ON RESOLUTION FINANCING IN THE BANKING UNION}

As a result, the potential application of ESM resources for resolution purposes was essentially amalgamated in the BRRD's structured and prescriptive approach to resolution financing, whereby a specific and rather inflexible (at least in principle) burden-sharing cascade must be allowed to run its course, before public resources can be used to bailout a bank. This has momentous implications for the Banking Union's prospective fiscal backstop. The final approach sets strict limits on the utilization of the ESM and, in particular, raises significant barriers to the activation of the DRI.

\section{THE BURDEN-SHARING CASCADE}

Specifically, according to the relevant legislative texts:

- Whenever a bank fails, the possibility of liquidation (a procedure which does not raise external financing issue) must first be considered. In particular, reiterating the principles of the BRRD, the legislation establishing the SRM emphasizes the 'exceptional' character of resolution actions: an insolvent bank should normally be wound up by way of normal insolvency proceedings; it should be maintained as a going concern through the exercise of resolution powers and the application of resolution tools only if this appears advisable for financial stability purposes. ${ }^{81}$

- Even when piecemeal liquidation (winding up) is inadvisable for reasons of systemic stability, a failed bank's resolution as a going-concern (whether as a whole or in part, and whether by retaining the old legal entity, through a merger with another entity or through a bridge bank) must be financed to the extent possible from private sources, both internal (existing stakeholders of the bank) and external (willing acquirers and/or investors of new capital).

- In particular, existing stakeholders - namely, shareholders, junior creditors and, depending on the circumstances, even senior creditors and depositors with deposits in excess of the guaranteed amount of $€ 100,000$ - are required to contribute to the absorption of losses and recapitalization of the bank

\footnotetext{
${ }^{80}$ SRM Regulation, rec. (18). The delegated acts and the regulatory and implementing technical standards, guidelines and recommendations issued in pursuance of the BRRD are equally binding on the decisionmaking bodies of the SRM as on the resolution authorities of member states outside the Banking Union. ${ }^{81}$ SRM Regulation, rec. (59); and BRRD, rec. (45)-(46).
} 
through a write down of their equity and debt claims and/or the conversion of debt claims into equity (application of the so-called 'bail-in tool'). The extent of write-down or conversion of claims will depend on the circumstances, but for each category of creditor included in the bail-in an upper limit is set by the principle that 'no creditor worse off than under normal insolvency proceedings' ${ }^{82}$ In order to minimize the impact of bail-in in the event of their resolution, banks might be tempted to reconfigure their liability structure and avoid issuing eligible liabilities. To ensure that this will not happen, the legislation on the SRM, ${ }^{83}$ reflecting once more the relevant provisions of the BRRD, 84 enables the $\mathrm{SRB}$ to impose on individual institutions a mandatory minimum requirement ('MREL') for own funds and other liabilities amenable to bail-in ('eligible liabilities'). ${ }^{85}$

- In this context, the relevant national DGS (a mechanism funded through levies on the banking industry, thus also a 'private' source in a restricted sense) may be required contribute to the financing of a member bank's resolution. However, its participation to open-bank resolution financing is limited to the amounts that it would be required to pay out to covered depositors, if the bank in question had been would up under normal insolvency proceedings. 86 Thus, the 'no worse off principle applies to the DGS's participation in similar manner as to creditors whose claims are included in the bail-in. Since losses from payments to covered depositors cannot logically occur unless the bank has negative net worth, the DGS responsibility may never go beyond bringing a bank's net worth back to zero. In other words, the DGS should only be asked to make a contribution in order to cover a net shortfall of assets over liabilities, but not to support with positive capital resources the failed bank or a bridge bank. ${ }^{87}$

- If the contributions of private parties are not enough, ${ }^{88}$ the appropriate national resolution fund or, for the countries of the Banking Union and from 1 January 2016 onwards, the SRM's SRF (once more, a mechanism which is funded by the banking industry, therefore from a financing perspective as 'private' as the DGS) can make a contribution, subject to strict conditions and up to a specific limit. Thus, the relevant resolution fund can only step in after a contribution amounting to no less than $8 \%$ of total liabilities (that is,

82 BRRD, rec. (5) and (73) and arts. 34(1)(g) and 74-75; SRM Regulation, rec. (78) and arts. 15(1)(g) and 20(5), (9).

${ }^{83}$ SRM Regulation, rec. (83)-(84) and art. 3(1)(49), 7(3)(d), 8(9)(o) and 12.

${ }^{84}$ BRRD, rec. (79)-(80) and art. 45.

${ }^{85}$ See also EBA, 'Consultation Paper: Draft Regulatory Technical Standards on Criteria for Determining the Minimum Requirement for Own Funds and Eligible Liabilities under Directive 2014/59/EU' (EBA/CP/2014/41, 28 November 2014).

${ }^{86}$ SRM Regulation, rec. (81) and (110) and art. 79; BRRD, rec. (71) and art. 109.

87 BRRD, rec. (110) and art. 109(1). Note that covered deposits now enjoy a higher priority ranking compared to other unsecured claims, thus reducing the availability of DGS contributions even for loss absorbency purposes; BRRD, rec. (111) and art. 108.

88 SRM Regulation, (101), fourth and fifth sentence. 
liabilities including own funds) has been made by stakeholders other than covered depositors by way of bail-in. ${ }^{89}$ In addition, the intervention is limited to medium-term financing of no more than $5 \%$ of total liabilities. 90

- If a bank remains undercapitalized even after all the aforementioned sources of resolution financing have been exhausted (either because they were depleted, or because the limits on their contribution were reached), but its continuation as a going concern appears imperative for reasons of systemic stability, recapitalization with public funds (whether national or panEuropean) may be considered. In these circumstances, the provision by the SRF of assistance in excess of the $5 \%$ limit is possible, but only if all unsecured, non-preferred liabilities, other than eligible deposits, have been written down or converted in full. ${ }^{91}$

While in the European resolution system the official decision-makers have discretion to select the most appropriate method of resolution and to apply any of the resolution tools set out in the BRRD, there is no discretion as to the application of the BRRD's burden-sharing cascade. This also applies to the resolution actions of the SRM. ${ }^{22}$ Assuming that the standing policy decisions and legal prescriptions will be applied faithfully expost, especially at a time of crisis, the cascade shifts the bulk of the burden from the taxpayer to the banks themselves, along with their investors and creditors.

\section{MANDATORY BAIL-IN}

Thus, the private sector (that is, the bank's immediate stakeholders by way of bailin, but also the broader banking industry through the relevant resolution fund) must finance the bailout to the tune of at least $13 \%$ of the failed bank's total liabilities, before public funds are used. ${ }^{93}$

Crucially, the principle of strict insistence on bail-in for all claimants other than covered depositors can be relaxed to a very substantial extent ex post, because both the BRRD and the SRM Regulation confer to the resolution authorities a discretion to exclude, for a variety of reasons, a wide range of creditors from the effects of bail in:

\footnotetext{
${ }^{89}$ BRRD, rec. (57), (73) and (75), and arts. 37(10)(a), 44(5)(a) and 44(8)(a); SRM Regulation, rec. (78) and (80) and art. 27(7)(a). The $8 \%$ minimum ratio cannot include reductions in own funds reflecting historical losses, if these had been made prior to the bank's valuation for the purposes of the resolution process; SRM Regulation, (80).

${ }^{90}$ BRRD, rec. (73)-(74), and arts. 44(5)(b) and 44(7); and SRM Regulation, rec. (78) and art. 27(7)(b).

${ }^{91}$ SRM Regulation, art. 27(9)-(10).

92 Moreover, the legislation sets a criterion for the decision-makers' choice of method: in principle, they should select the resolution scheme that is the least costly for the SRF; SRM Regulation, rec. (85).

${ }^{93}$ The justification is that ' $[\mathrm{i}] \mathrm{t}$ should be the financial industry, as a whole, that finances the stabilisation of the financial system'; BRRD, rec. (103), third sentence; and, in identical terms, SRM Regulation, rec. (100), third sentence.
} 
It should be possible to exclude or partially exclude liabilities in a number of circumstances, including where it is not possible to bail-in such liabilities within a reasonable timeframe, where the exclusion is strictly necessary and is proportionate to achieving the continuity of critical functions and core business lines, or where the application of the bail-in tool to liabilities would cause a destruction in value such that losses borne by other creditors would be higher than if those liabilities were not excluded from bail-in. It should also be possible to exclude or partially exclude liabilities where necessary to avoid the spreading of contagion and financial instability which may cause serious disturbance to the economy of a Member State. [...] [Moreover,] authorities should give consideration to the consequences of a potential bailin of liabilities stemming from eligible deposits held by natural persons and micro, small and medium-sized enterprises above the coverage level provided for in Directive 2014/49/EU. ${ }^{94}$

Leaving aside questions relating to the sufficiency of DGSs' pre-funded resources, ${ }^{95}$ the reason for which even a well-funded DGS's intervention may not be sufficient lies precisely in the existence of secured claims, which are excluded automatically, together with the possible extension of the safety net beyond covered deposits, through the discretionary creation of additional classes of protected creditors. ${ }^{96}$ This necessitates the introduction of arrangements for additional external financial support, either in the form of the industry-funded resolution funds or, in extremis, by way of public assistance and/or use of the common fiscal backstop.

\section{SINGLE RESOLUTION FUND (SRF)}

While in the Banking Union the DGSs will remain national, a common resolution fund will be established. The official justification for the SRF maintains that this is

\footnotetext{
94 SRM Regulation, rec. (77).

95 By 3 July 2014, the available financial means of each DGS must have reached a target level of at least $0.8 \%$ of its members' total covered deposits; DGSD, art. 10(2), first subpara.

96 The impact assessment accompanying the Commission proposal for the BRRD puts the covered deposits of an average European bank at around $20 \%$ of total liabilities; Commission Staff Working Document SWD(2012) 166/3, p. 131 (Table 5). The same source estimates the share of non-bail-inable items (covered deposits and other non-bail-inable debts) in banks' total liabilities based on two policy options: comprehensive bail-in, in which unsecured debt, uncovered deposits and unsecured interbank exposures with more than 1 month original maturity are subject to bail-in; and restricted bail-in, in which only unsecured long term debt and uncovered deposits with more than 1 year original maturity are included. According to this estimation, an average European bank's non-bail-inable liabilities amount from $61.5 \%$ to $78.6 \%$ of total liabilities, depending on the policy option chosen. For an average large banking group, the share is even higher, at a range from $69.7 \%$ to $86.7 \%$. ibid., pp. 130-1 and 133 (Table 6). It should be noted that the exact volume of banks' covered deposits is not known, but Daniel Gros and Dirk Schoenmaker, 'European Deposit Insurance and Resolution in the Banking Union', (2014) 52 Journal of Common Market Studies 529, 540, give a rough estimate of about $€ 5,980$ billion for all euro area banks.
} 
essential for the attainment of the Banking Union's two key objectives, namely, the breaking of the perverse link between sovereigns and the banking sector and the equalization across countries of banks' bailout prospects, without which a bank's place of establishment comes to dominate its borrowing conditions. ${ }^{97}$ Strictly speaking, for these objectives to be met, it would be sufficient to provide equal access for all banks in the region to a credible cross-national fiscal backstop. Moreover, the choice in favor of a single resolution fund is hardly compatible with the continuing separation of the DGSs. On the other hand, there is no question that the integration of industry-based financing arrangements contributes to the credibility of the resolution system, because it makes available in respect of any particular resolution action an amount of pre-funded resources that exceeds by far what could be collected by way of bank contributions at the national level. In this manner, the SRF provides significant reassurance that the BRRD's insistence on a sizeable contribution by the private banking sector as a prior condition for publicly-financed bailouts will be respected in practice, even in relation to large banks.

The SRF will be pre-funded with bank contributions, which will be raised at the national level but pooled at Banking Union level. As mentioned above, a separate intergovernmental agreement establishes the modalities for the transfer of the national contributions to the SRF and the conditions for their progressive merger in a single pool. ${ }^{98}$ Contributions from individual banks must be raised $e x$ ante, in order to reach a specified target level of pre-funding, which is intended to ensure that a critical mass of resources will be available under any circumstances and avoid the procyclical, destabilizing effects of an expost levy on other banks, especially in situations of systemic crisis. ${ }^{99}$ The target level for the SRF's prefunded financial means has been set at no less than $1 \%$ of the depositguarantee-covered deposits of all banks authorized in the Banking Union. ${ }^{100} \mathrm{It}$ must be reached gradually over a period of eight years, starting from 1 January 2016; the period may be extended by up to four more years, if the SRF has made cumulative disbursements of more than $0.5 \%$ of covered deposits, that is, more than half the target level. ${ }^{101}$ Thereafter, if the SRF's financial means fall below the

\footnotetext{
${ }^{97}$ SRM Regulation, rec. (19), second sentence, and (100), second sentence.

${ }^{98}$ IGA on the SRF.

99 SRM Regulation, rec. (102)-(104) and art. 70; this is consistent with the target level for national resolution funds in the BRRD, art. 102(1). In addition to a flat, pro-rata component based on relative size, the contributions of individual institutions may also include a component adjusted in accordance to their risk profile, so as to ensure fairness in the allocation of the financial burden and provide incentives for less risky behavior; SRM Regulation, rec. (109) and art. 70(2), (6); BRRD, rec. (107) and art 103(7). 100 SRM Regulation, rec. (105) and art. 69(1), in conjunction with art. 3(1)(11) and DGSD, arts. 2(1)(3)-(5), 5 and 6 . In the future, the target may be redefined to substitute total liabilities for covered deposits as the basis for the calculation and/or to establish a minimum absolute amount of prefunding; SRM Regulation, rec. (105) and art. 94(1)(a)(vi).

101 SRM Regulation, rec. (106) and art. 69(1) and (3). Thus, the intended period for the built-up of the SRF ends a year before the equivalent period for the national resolution funds of the member states outside the Banking Union, which ends on 31 December 2024; BRRD, art. 102(1)-(2).
} 
target, they must be replenished through additional regular contributions. ${ }^{102}$ Contributions can also be imposed on an extraordinary basis and up to a limit ex post, if the prefunded resources prove insufficient to cover the cost of resolution actions of the SRM. ${ }^{103}$ In addition, if the ex ante and ex post contributions are not immediately accessible or are insufficient for the SRF's intended intervention, the legislation enables the SRF to borrow additional sums and/or enter into other contractual arrangements for the purpose of attracting third-party financial support. ${ }^{104}$

The resources of the SRF must be used exclusively for the implementation of resolution tools and resolution powers. ${ }^{105}$ More precisely, the SRF can provide extend short-term funding to a failed bank or a bridge entity, provide guarantees to potential purchasers of a failed bank or inject capital in a bridge entity; but it may not be used directly to absorb losses of the failed bank or to recapitalize it. ${ }^{106}$ Any decisions on the use of the SRF will be taken centrally by the SRM's decisionmakers. (This should be contrasted with decisions to provide public financial support to banks in resolution, which due to their fiscal nature are reserved for the national governments acting separately or, if the single fiscal backstop must be activated, jointly in the ESM.107) Significantly, although the SRF resources are drawn from the private banking sector, not the taxpayer, any resolution action involving SRF financing can only be undertaken with the approval of the Commission, exactly as if it were a form of state aid. ${ }^{108}$ The decision of the Commission approving the SRF aid may impose, inter alia, conditions regarding the recipient bank, including burden-sharing requirements, restrictions on the payment of dividends or on capital management transactions, prohibitions on group expansion or aggressive commercial strategies, requirements concerning market shares, pricing or product features, requirements for restructuring plans,

\footnotetext{
102 The resources raised in this manner must be invested in safe, diversified and liquid assets, in order to protect the SRF's value and to ensure its availability; SRM Regulation, rec. (111), and art. 75.

103 SRM Regulation, rec. (102) and art. 69-71; see also BRRD, rec. (105)-(107), and art. 102-104.

104 SRM Regulation, rec. (102) and art. 73. The legislation further permits borrowing arrangements between the SRF and the resolution funds of member states outside the Banking Union, as well as the creation of public financial facilities in favour of the SRF; SRM Regulation, arts. 72 and 74 . In this context, the legislation envisages that prior to the date of application of the provisions on the SRF (1 January 2016), the SRB in cooperation with the participating member states will 'develop the appropriate methods and modalities permitting the enhancement of the borrowing capacity' of the SRF; SRM Regulation, rec. (107), third sentence, in conjunction with art. 99(2).

${ }^{105}$ SRM Regulation, rec. (101).

${ }^{106}$ SRM Regulation, rec. (100), first sentence, and art. 76; BRRD, rec. (103), first sentence, and art. 101. 107 SRM Regulation, rec. (19), fifth and sixth sentences, and art. 6(6) and 57(2). See also Declaration of the Republic of Bulgaria, the Czech Republic, the Federal Republic of Germany, the Republic of Estonia, the Republic of Malta, Romania, the Slovak Republic and the Republic of Finland on the Agreement on the Transfer and Mutualisation of Contributions to the Single Resolution Fund made upon signature. 108 SRM Regulation, rec. (30) and (75), third sentence, and art. 18(9), third sentence, and 19. In fact, the same applies even to resolution actions requiring nothing more than DGS assistance in support of a private solution, without use of SRF resources; SRM Regulation, rec. (47), (55).
} 
governance and disclosure requirements, and even requirements relating to the sale or partial sale or liquidation of the recipient bank. ${ }^{109}$

In the SRM, decisions concerning the resolution of particular banks are taken by the SRB in its executive session. Nonetheless, when the proposed resolution action involves large-scale use of SRF resources, that is, support in excess of $€ 5$ billion, 110 any member of the SRB can request the referral of the matter to the plenary session. The plenary must also review the situation and give guidance to the executive session when the $€ 5$ billion threshold has been reached through a series of resolution actions over the previous 12 -month period. The involvement of the plenary in these cases is explained by the need to ensure a nondiscriminatory utilization of SRF resources while avoiding its depletion. ${ }^{111}$

Overall, the SRF is intended to provide the primary source of outside financing for the resolution of banks within the Banking Union. As already mentioned, except if all unsecured, non-preferred liabilities have been written down in full, its intervention will be capped by the prescribed limit of $5 \%$ of total liabilities. More to the point, the SRF's potential intervention will always be subject to the absolute limit set by its total available resources. Thus, it is only in situations where the liabilities which are exempted from bail-in are substantial and the Fund's contribution proves to be insufficient to cover the resulting financing gap that an intervention with public funds may be justified. ${ }^{112}$ As we will presently see, however, this does not necessarily imply an activation of the common fiscal backstop.

\section{THE ESM'S DIRECT RECAPITALIZATION INSTRUMENT (DRI)}

To be sure, once the full gamut of Banking Union arrangements becomes operational on 1 January 2016, the ESM's DRI will become available for bank recapitalization purposes. When agreement on the instrument's main features was reached in the Eurogroup in June 2013, the accompanying statement reiterated that the DRI's objective was 'to preserve the financial stability of the euro area as a whole and of its member states in line with Article 3 of the ESM Treaty, and to help remove the risk of contagion from the financial sector to the sovereign by allowing the recapitalization of institutions directly.. 113 The way in which the instrument has been implemented, however, raises doubts as to its practical significance.

\footnotetext{
${ }^{109}$ SRM Regulation, rec. (30), and art. 19(3), fifth subpara.

110 The threshold is doubled if the support takes the form of low-risk liquidity provision, e.g. liquidity assistance to a solvent institutions against good collateral.

111 SRM Regulation, rec. (33).

112 Cf. SRM Regulation, rec. (79).

113 'ESM Direct Bank Recapitalisation Instrument - Main Features of the Operational Framework and Way Forward' (20 June 2013).
} 
In particular, the ESM DRI Guideline, ${ }^{114}$ which details the DRI's rules of operation, establishes exceptionally exacting preconditions for its activation. ${ }^{115}$ The rules raise significant barriers to the activation of the DRI even in situations where recapitalization with public funds appears justified and/or reduce its usefulness.

Thus, assistance through the DRI is available only to banks whose recapitalization with public funds is considered indispensable, because they are (a) systemically important or otherwise likely to threaten through their failure the financial stability of the euro area as a whole or, at least, of one or more countries in the area, but (b) unable (or expected to become unable in the near future) to meet their capital requirements, as specified by the ECB in its supervisory capacity, (c) unable to attract sufficient new capital from the private sector (existing shareholders or new market investors), and (d) unable to cover fully the estimated capital shortfall by way of bail-in. 116

As a result, the use of the DRI for precautionary purposes is excluded. ${ }^{117}$ Thus, any precautionary public assistance in the form of participation in the equity of a bank which is still solvent will need to take place under the responsibility of the relevant national government and on its own account. ${ }^{118}$

Moreover, despite the move to centralized banking supervision in the form of the SSM, the primary responsibility for bailing out an insolvent bank remains with the home member state. Accordingly, for the activation of the DRI a request for assistance must be submitted by an ESM member (that is, a country of the euro area). ${ }^{119}$ The request may be made both by countries within a macroeconomic adjustment programme and by non-programme countries. ${ }^{120}$ The financial assistance to institutions may be requested by ESM Members within or outside the confines of a macroeconomic adjustment programme. In all cases, however, the requesting country must itself be unable to provide itself the requisite financial assistance to the institution(s) concerned without jeopardizing its own fiscal sustainability or continuous access to the capital market. ${ }^{121}$

The country eligibility criterion takes explicitly into account the alternative of indirect bank recapitalization by the ESM, by way of a loan to the relevant national

\footnotetext{
114 ESM, 'Guideline on Financial Assistance for the Direct Recapitalisation of Institutions' (8 December 2014). See also ESM, 'FAQ on the ESM Direct Recapitalisation Instrument' (8 December 2014).

115 See Bert Van Roosebeke, 'The ESM'S Direct Recapitalisation of Banks: Looking Forward in Backstop-Questions', Stiftung Ordnungspolitik, Centrum für Europäische Politik (cep), Policy Contribution No. 14/01 (August 2014).

${ }^{116}$ ESM DRI Guideline, art. 3(1).

117 ESM DRI Guideline, art. 8(1).

118 BRRD, rec. 41 and art. 32(4)(d)(iii); and SMR Regulation, rec. 57 and art. 18(4)(d)(iii).

${ }^{119}$ ESM DRI Guideline, art. 4(1).

${ }^{120}$ ESM DRI Guideline, art. 1(4), first sentence. With the unanimous agreement of the ESM's members, the DRI may also be used 'retroactively', to replace in part or in full the indirect bank recapitalization assistance extended by the EFSF and the ESM as part of an existing country bailout programme; ESM DRI Guideline, art. 14.

${ }^{121}$ ESM DRI Guideline, arts. 2(1) and 3(2)(a).
} 
government ${ }^{122}$; unless this form of assistance is bound to trigger by itself a drastic deterioration of the recipient country's fiscal prospects, it should be preferred over the DRI. In other words, the DRI is only available in situations where a country is unable to finance on its own account a bailout without thereby undermining its fiscal prospects; in all other cases, the national government must provide itself financial support to the troubled $\operatorname{bank}(\mathrm{s}),{ }^{123}$ either by raising the requisite sums in the capital market or, in the worst case, by accessing the ESM for a loan. ${ }^{124}$ Beyond the stringency of the eligibility criteria, one objection to this approach is that, unless it is already within a country programme, even an eligible country might be reluctant to apply for the activation of the DRI, because such a request would constitute in itself an admission of severe fiscal weakness, which could trigger the negative bank-sovereign spiral that it is, in theory, intended to preclude.

The assessment of compliance with the eligibility criteria is entrusted, in relation to the bank concerned, to the Commission in liaison with the ESM's Managing Director, the competent resolution authority and the ECB in its capacity as supervisor and, in relation to the requesting country, to the Commission in liaison with the ECB and, wherever appropriate, the IMF (that is, to the Troika of the post-crisis country bailout programmes). Based on this assessment, the ESM Board of Governors (that is, the euro area's ministers of finance) takes a decision in principle to grant financial assistance. ${ }^{125}$

Crucially, like any other assistance-granting decision of the ESM, this decision is reached by 'mutual agreement' (that is, unanimity). ${ }^{126}$ This gives an effective veto to each and every government in the euro area (and to each national parliament, which may be called to vote on the proposed ESM action). Where the facility is drawn in tranches, the same requirement of unanimity applies to decisions of the ESM Board of Directors authorizing the disbursement of the second and subsequent tranches. ${ }^{127}$ The ESM's direct contribution to a bank's recapitalization on this basis takes place after the writing down or conversion of the full amount of all unsecured, non-preferred liabilities (excluding eligible deposits) and the aforementioned 5\% contribution of the resolution fund. ${ }^{128}$ The maximum amount for the ESM's contribution to a bank's recapitalization is

\footnotetext{
${ }^{122}$ ESM DRI Guideline, arts. 2(1), third sentence, and 3(2)(a), first sentence.

${ }^{123} \mathrm{BRRD}$, arts. 56-58.

${ }^{124}$ ESM Treaty, art. 15.

${ }^{125}$ ESM DRI Guideline, art. 4(2), third sentence, and (3).

${ }^{126}$ ESM Treaty, art. 5(6)(f) and (g). 'Mutual agreement' means 'unanimity of the members participating in the vote', with abstentions excluded from consideration; ESM Treaty, art. 4(3). In emergency situations, where the Commission and the ECB both conclude that a failure to urgently adopt a decision regarding financial assistance would threaten the economic and financial sustainability of the euro area, a qualified majority of $85 \%$ of the votes cast is sufficient; ESM Treaty, art. 4(4), first subpara. It should be noted that the quorum for taking any decision in the ESM's collective organs (Board of Governors and Board of Directors) is $2 / 3$ of the members with voting rights representing at least $2 / 3$ of the voting rights; ESM Treaty, art. 4(2).

${ }^{127}$ ESM DRI Guideline, art. 6(3).

${ }^{128}$ ESM DRI Guideline, art. 8(3). Slightly more lenient rules apply until 31 December 2014, whereby it is sufficient to achieve $8 \%$ bail-in followed by a contribution of the national resolution fund up to its available resources; ESM DRI Guideline, art. 8(2).
} 
specified in the financial assistance facility agreement with the requesting country, and is based a thorough valuation, including stress testing, of the bank's assets and any forthcoming contributions by private investors and the national government; it must be of such magnitude so as to allow the bank to fully meet the requisite level of capital adequacy, as determined by the ECB as supervisor. ${ }^{129}$

Oddly, even though the DRI is supposed to provide an absolute last resort by preventing contagion from the financial sector to fiscally weak sovereigns, ${ }^{130}$ the latter are still required to contribute financially to the assistance programme - in fact, by taking the first hit! Thus, the requesting state is asked to make a first contribution to the recapitalization of the troubled bank by injecting all the capital that may be needed to restore the bank's Common Equity Tier 1 ratio (that is, the sum of common shares and retained earnings divided to risk-weighted assets) to the legal minimum of $4.5 \% .{ }^{131}$ In other words, the ESM will only participate in the recapitalization to the extent necessary to bridge the gap between the $4.5 \%$ level and the ECB-prescribed level of capital adequacy. Significantly, this burdensharing scheme is based on a robust valuation of assets, which includes their subjection to a sufficiently prudent stress-testing, thus further increasing the potential funding needs. Beyond the $4.5 \%$ requirement, the national contribution is also subject to a floor of $10 \%$ (or, until the end of 2016, 20\%) of the ESM's contribution. ${ }^{132}$ A more lenient treatment is possible when the requesting country is not able to contribute up-front due to fiscal reasons, but only with the unanimous agreement of the ESM Board of Governors and on the conditions that the country (a) indemnifies the ESM for any loss attributable to the country's nonparticipation and (b) agrees to macroeconomic conditionality. ${ }^{133}$

Any decision to use the DRI entails conditionality, both for the bank concerned and the requesting country. To start with the bank must be restructured, based on a plan drawn by the ESM jointly with the bank and the country, in consultation with the ECB as supervisor and the SRB. ${ }^{134}$ This should ensure the bank's viability following recapitalization. ${ }^{135}$ Since the recapitalization exercise is deemed to be a form of public assistance, the restructuring plan

\footnotetext{
${ }^{129}$ ESM DRI Guideline, arts. 4(6), (7)(c) and 7. As a general rule, the ESM will acquire common shares in the troubled bank, but the use of other instruments that count towards the regulatory capital requirements (e.g., special shares, hybrid capital instruments or contingent capital) is possible under certain conditions; ESM DRI Guideline, art. 10. The resulting participation of the ESM as shareholder of the original institution or the bridge bank is of temporary nature, and the ESM will seek appropriate opportunities for disinvestment through the sale or redemption of the relevant instruments; ESM DRI Guideline, art. 12.

${ }^{130}$ ESM DRI Guideline, art. 2.

${ }^{131}$ ESM DRI Guideline, art. 9(1)(a).

132 ESM DRI Guideline, art. 9(1)(b) and (2).

133 ESM DRI Guideline, art. 9(3)-(4).

134 ESM DRI Guideline, art. 4(5).

135 ibid.
} 
requires the Commission's approval, which will be given subject to specific conditions. ${ }^{136}$

Additional conditions will be set outside the state aid framework in relation both to the bank and the country, based on the ESM's own legal framework. Thus, the bank will be subject to further institution-specific conditions, defined by the ESM's Managing Director in liaison with the Commission, the ECB as supervisor and the requesting country and incorporated in the institution-specific agreement entered into between the ESM, the country and the bank. ${ }^{137}$ Such conditions can affect the bank's management and internal policies, e.g., by setting limits on management remuneration and the dividend policy. More generally, although there is no intention to involve the ESM in day-to-day management decisions, ${ }^{138}$ the ESM will be able to influence key aspects of the bank's future business model and governance, both through the institution-specific agreement and through its representation in the institution as shareholder. ${ }^{139}$

In its turn, the requesting country must agree on a Memorandum of Understanding ('MoU'), imposing conditionality relating to its financial-sector policy and even, if this appears appropriate, its macroeconomic situation. ${ }^{140}$ Negotiations on the actual content of the MoU will take place separately from the determination of the institution-specific conditionality, and will involve the requesting country, on the one hand, and the Commission in liaison with the $\mathrm{ECB}$, the ESM's Managing Director and, if appropriate, the IMF, on the other, in a manner reminiscent of the Troika's role in country bailout programmes. ${ }^{141}$

Provision has been made for the revision of the DRI's guidelines every two years from the instrument's introduction, in order to take into account the deepening of the Banking Union and the gradual absorption of the national banking systems' legacy problem assets, as well as for a more comprehensive review after ten years, to decide whether the instrument should be continued or abandoned. ${ }^{142}$ In particular, the periodic reviews should consider the continuing appropriateness of the requirement of a first capital contribution by the requesting state. ${ }^{143}$

Under the present arrangements, however, it is clear that, even after 2016 (when the SRM will be fully operational), national governments will be saddled the primary financial responsibility in relation to publicly assisted bank bailouts. Even where a government finds itself in the unenviable position of needing to finance

\footnotetext{
136 TFEU, arts. 107-108; ESM DRI Guideline, arts. 1(3) and 4(4), (11).

137 ESM DRI Guideline, art. 4(7)(b), (8). On monitoring of compliance with the institution-specific conditions and covenants relating to non-compliance, see ESM DRI Guideline, art. 5(2), (8).

138 ESM, 'FAQ on the ESM Direct Bank Recapitalisation Instrument' (8 December 2014), answer to q. 15.

${ }^{139}$ ESM DRI Guideline, art. 11.

140 ESM DRI Guideline, arts. 1(4), second sentence, and 2(2). Even when the country is already in a full macroeconomic adjustment programme, specific conditionality, relevant to the use of the DRI, may be imposed.

${ }^{141}$ ESM DRI Guideline, art. 4(7)(a).

142 ESM DRI Guideline, art. 15.

143 ESM DRI Guideline, art. 15(1).
} 
the recapitalization of systemically important banks, while being fiscally too weak to do so without external support, the recapitalization will take place, as a rule, on the government's own account, with the ESM providing only indirect assistance, in the form of a loan. In contrast, in view of its very strict preconditions and terms (not least, the need for unanimity in the ESM's Board of Governors for its activation), the DRI is unlikely to be used in other than wholly exceptional circumstances. Even then, the country will need to share a considerable portion of the financial burden - and this, despite the fact that it is no longer in charge of the troubled bank's supervision!

The resulting confinement of the DRI to a limited, supporting role is recognized by the ESM itself in unambiguous terms:

When the instrument was first proposed, it was supposed to cut the link between troubled credit institutions and sovereigns. However, it soon became apparent that the remaining building blocks of the banking union would most likely achieve this aim without the need for DRI to provide substantial funds.

More specifically, the bail-in of private investors (in accordance with the Bank Recovery and Resolution Directive), and the contribution of a national resolution fund (or Single Resolution Fund from 2016) as a precondition for the DRI to be used has shifted the bulk of potential financing from the ESM to the institutions themselves, along with their investors and creditors. With all the components of banking union set to become operational by January 2016, the ESM direct recapitalisation instrument will only be applied when all burden sharing arrangements specified in the DRI Guideline prove insufficient to return a bank to viability, the eligibility criteria regarding the requesting ESM Member and institution requiring recapitalisation [...] are met and if indirect recapitalisation is not possible. ${ }^{144}$

The DRI is thus relegated almost to a footnote in the Banking Union's overall design. From 2016 onwards, when the BRRD will be fully effective and the SRM fully operational, the DRI will be just one element of a highly complex European resolution regime, supported by a variety of financing arrangements. Its restrictive conditions of eligibility suggest that it may not be available in all pertinent cases, even when the national government is financial weak. The instrument would appear better suited to the recapitalization of major systemic banks. For the rest, indirect ESM support for bank recapitalization remains a more practicable alternative. 


\section{QUESTIONING THE SUFFICIENCY OF THE FINANCING ARRANGEMENTS}

Even so, the mere existence of a credible fiscal backstop can play a key role in assuaging market concerns, facilitating the exit from the crisis and enabling the reintegration of banking markets in the euro area. In this context, of course, credibility hangs on the sufficiency of the resources that can be mobilized in case of need.

Following political agreement in the Eurogroup, the DRI is currently subject to an overall cap of $€ 60$ billion (out of the ESM's total lending capacity of $€ 500$ billion). The cap was considered necessary in order to preserve the ESM's capacity for lending to weak sovereigns, to minimize risk (since acquiring an equity participation in weak banks is considered riskier than lending to weak sovereigns, including when the loan is granted for indirect bank recapitalization purpose), and also to ensure that the ESM retains its AAA rating (which might otherwise be jeopardized). ${ }^{145}$ On the other hand, this size appears quite modest and inadequate to break conclusively the bank-sovereign loop. An increase of the maximum amount is, of course, possible, but (just like each particular activation of the instrument) it requires the unanimous agreement of the euro area countries, with governments' acquiescence depending in many cases (most conspicuously, in the case of Germany, which contributes some $27 \%$ of ESM resources) on prior approval by the national parliaments. As for the present $€ 60$ billion cap, it has caused considerable consternation. Amongst other critics, the IMF has openly expressed doubts about the planned backstop, noting that 'centralized resolution resources may not be sufficient to handle stress in large banks'. ${ }^{146}$

Is the criticism justified? It is not easy to say! One cannot predict with any accuracy the recapitalization needs of major European banks in a future systemic crisis. What is certain is that the euro area is home to a very large banking sector, with total assets amounting to more than three times the region's GDP, 147 concentrated for the most part in the hands of large systemic banks, including a number of global systemically important banks, whose recapitalization could conceivably require huge resources. In 2011, nine of the region's thirteen largest banks (with assets of over $€ 500$ billion) were based in fiscally weak large countries, namely, France, Spain and Italy (the remaining being German or Dutch). The total assets of these nine banks ranged from $€ 1,965$ billion (BNP Paribas) to $€ 598$ billion (BBVA), while their European assets alone amounted to

\footnotetext{
145 ibid., answers to q. 16-17.

146 IMF, '2014 Article IV Consultation with the Euro Area: Concluding Statement of the IMF Mission' (June 19, 2014), para. 10. In the final staff report, the emphasis is not on the insufficiency of the financial resources, but on the exceedingly demanding thresholds for accessing the mechanism, but a reference to the need for 'sufficient common backstops' can still be found in a table summarizing policy recommendations; IMF, Euro Area Policies: Staff Report for the 2014 Article IV Consultation with Member Countries' (25 June 2014), esp. paras. 20 and 51 and Table 2.

147 According to the ECB's monetary statistics, in December 2011 total assets amounted to some $€ 32,5$ trillion, for a GDP of less than $€ 10$ trillion.
} 
between $€ 1,739$ (Crédit Agricole) and $€ 390$ billion (BBVA). The Tier I capital ranged from $€ 71$ billion (BNP Paribas) to $€ 28$ billion (Crédit Mutuel). ${ }^{148}$ The failure of any of them -even assuming that it would take place in isolation, rather than as part of a wider systemic crisis- would require the mobilization of huge financial resources. This is also proven by the recent crisis, when certain large banks received public assistance in excess of $€ 100$ billion. As an example, the public assistance provided by Germany to Hypo Real Estate amounted to $€ 134$ billion in total - although only a small fraction ( $€ 9.8$ billion) related to capital injections, the rest comprising state guarantees. ${ }^{149}$ Regarding the system-wide situation in the aftermath of the crisis, the ECB's recent comprehensive assessment of 130 large European banks ${ }^{150}$ identified capital shortfalls in 25 banks, with a combined shortfall of just $€ 24.6$ billion (large part of which had already been covered by the banks by the time of publication of the results). ${ }^{151}$ However, academic analysts, who used multiple benchmark stress tests to produce alternative estimates, came up with capital shortfalls ranging from $€ 82$ billion to $€$ 767 billion, depending on the model. ${ }^{152}$ Compared to the highest estimates, the DRI in its present size pales into insignificance.

Nonetheless, in contrast to the 2012 debates, when the fiscal backstop was intended to provide the primary means for addressing systemic bank troubles, especially in the fiscally less robust countries, now it would be wrong to judge the DRI separately from the other legal and financing arrangements of the BRRDbased resolution regime. To start with, the new regime place strong emphasis on the avoidance of regulatory forbearance; assuming that resolution will actually be triggered as early as possible, an accumulation of losses may be prevented and the necessary correction may require less resources. In addition, the tough bail-in requirements place a very significant part of the resolution cost on the shoulders of the failed bank's existing stakeholders. Again assuming early identification of the failure, this will leave a relative small funding gap, if any. This need not be covered out of resources allocated to the DRI. As we have discussed already, the relevant DGS should also make a contribution; and the BRRD cascade mandates

\footnotetext{
148 Data as reported by Daniel Gros and Dirk Schoenmaker, 'European Deposit Insurance and Resolution in the Banking Union' (2014) 52 Journal of Common Market Studies 529, at 541, Table 2.

149 Figures provided by the German Federal Agency for Financial Market Stabilisation (FMSA), http://www.fmsa.de/export/sites/standard/downloads/20140630 Overview of SoFFin measures.pdf.

${ }_{150}$ See above, $n .148$ and accompanying text.

${ }^{151}$ ECB, 'Aggregate Report on the Comprehensive Assessment' (October 2014), 6.

152 Viral V. Acharya and Sascha Steffen, 'Falling Short of Expectations? Stress Testing the Eurozone Banking System', CEPS Policy Brief No. 315 (15 January 2014). The same analysts attribute the startling divergence to the results of large banks in large countries, such as France and Germany, which in the ECB's comprehensive assessment appeared not to have capital shortfalls - possibly because systemic risk and feedback effects from the financial sector in the real sector, which are captured in the market data, were completely ignored in regulatory assessment. They further note that regulatory stress-test outcomes may be heavily affected by regulatory discretion in measuring what is 'capital' and especially by the riskweighting of assets when calculating the prudential capital requirement. Viral Acharya and Sascha Steffen, 'Making Sense of the Comprehensive Assessment', VoxEU.org, 29 October 2014, http://www.voxeu.org/article/making-sense-ecb-s-comprehensive-assessment.
} 
the use of the resolution fund before public recapitalization assistance can be extended.

With prefunding gradually rising to $1 \%$ of covered deposits, the euro area's SRF has a target level of approximately $€ 55$ billion (based on the 2011 volume of covered deposits). The SRF can also increase its firepower by borrowing, or by raising ex post contributions (although the latter may not be advisable in the midst of a crisis, so that the primary use of ex post contributions may be to repay borrowings); and there is an agreement in principle for the eventual introduction of a common backstop, to provide the SRF with public bridge financing when its own resources are not sufficient. 153 Just like the DRI, the size of the SRF has been criticized as insufficient. ${ }^{154}$ For a proper assessment of the situation, however, it is necessary to add up all prefunded or precommitted sources of financing - the SRF's $€ 55$ billion, the relevant DGS's level of prefunding, as well as the DRI's 60 billion -, because they can all contribute in covering the funding gap (and provide cumulative layers of reassurance ex ante). The combined amounts of prefunding appear substantial, even though not 100\% convincing. The non-mutualization of the national DGSs is an evident problem (only partially alleviated by the possibility of mutual lending between them). On the other hand, the situation appears under a better light, if one also takes into account the borrowing capacity of the SRF, the national contribution to recapitalization when the DRI is used, but also the possibility of indirect bank recapitalization by the ESM, which raises very significantly the cap on available resources.

All in all, in view of the emphasis placed by the new European legislation on strict enforcement (including by way of extensive bail-in of stakeholders) and of the strict limits on the nature and extent of any external (industry-funded or public) assistance, it would be fair to say that the combined size (precommitted and potentially callable resources) of the various financial instruments may be enough for the operation of the resolution regime in a normalized environment. ${ }^{155}$ When fully built up, the resources might even suffice for the resolution of one of the largest European banks, assuming that this takes place in relative isolation. It is certainly possible that additional financial means will be needed in the event of a wider systemic crisis. Ad hoc bailout packages may then appear necessary. If so, the main impediment would not be the 'low' level of prefunded financial instruments, because there is simply no good reason to fully cover in advance the cost of a tail risk.

In this eventuality, the political dynamics are bound to result in a greater willingness to mobilize public resources in support of shaky banks, in various

\footnotetext{
153 'Statement of Eurogroup and ECOFIN Ministers on the SRM Backstop' (18 December 2013).

154 According to one estimate, to be fully credible, the fund should have a size of over $€ 500$ billion, mostly prefunded, with a common DGS contributing, for good measure, another $€ 96$ billion; Mats Persson and Raoul Ruparel, 'The Eurozone Banking Union: A Game of Two Halves', Open Europe working paper (December 2012), pp. 10-11.

155 Thomas Huertas and María J. Nieto, 'How much is enough? The Case of the Resolution Fund in Europe', VoxEU.org, 18 March 2014, http://www.voxeu.org/article/ensuring-european-resolution-fundlarge-enough.
} 
forms (central bank liquidity assistance, state guarantees, state loans to the SRF or an increase in the capacity of the ESM, or even full nationalization of weak banks). The true limitation would then lie in the inflexibility of the current approach to resolution, as entrenched in the BRRD and related legal texts. Due to its formal legal character, the new system may operate as a major structural straightjacket, hampering the shift for an $e x$ ante commitment to rigorous enforcement to an $e x$ post stance of extensive forbearance. A resolution regime specifically designed to shift the costs of resolution back to the banks' private shareholders and to set relatively strict limits on taxpayers' exposure is inherently unable to provide a credible promise that all and sundry will be salvaged. Irrespectively of the financial arrangements backstopping the system, the legal strictures of the BRRD will tend to increase uncertainty in the run up to a crisis (since the prospect of bail-in will cause consternation in the ranks of non-protected claim holders). This, however, is a price that the legislator has decided to pay in order to restore market discipline, improve the banking industry's incentive structure by containing moral hazard, and remove the implicit subsidy to large banks by ensuring that no bank is too big to fail.

\section{A STABLE COMPROMISE?}

Turning to the broader picture, the move to the Banking Union has clearly been the most significant regulatory outcome of the crisis - a change of regime, rather than an act of institutional tinkering. The implications for the development of the European financial markets, as well as for the operation and viability of the monetary union, are bound to be profound. The transition to the new regime is not yet complete. Its completion will take years. But already the basic structure has been put in place.

Despite divergences between the euro area's governments, in so far as the administrative side is concerned, the architecture of the Banking Union by and large conforms to the original blueprint, as set out by the European Commission in the second semester of 2012. On the other hand, with regard to the financing of resolution actions, the emerging European resolution regime departs from, if it does not subvert, the original assumptions of the Banking Union project. In 2012, the expectation was that bailouts would continue to dominate bank resolution for the foreseeable future, roughly on the same lines as in the early phase of the global financial crisis, and that the shift to a centralized system of supervision would simply make possible the mutualiziation, through the ESM, of the costs of 
recapitalization with public funds. ${ }^{156}$ The eventual legislation, however, provides clear directions on the appropriate treatment of failed banks and sets strict limits, at least in principle, on the passing on of losses to taxpayers. And a shift in political positions by Germany and other strong economies has effectively led to the postponement sine die of the arrangements relating to the supranational financing of resolution; and, in any event, the mutualization of 'legacy' problems remains unlikely.

In terms of the longer term development of the euro area's banking industry, the current SRM's financing arrangements leave much to be desired. Even if the targeted levels of funding are sufficient, the modalities are unlikely to contribute to the equalization of monetary and banking conditions in the euro area. As long as the fiscal backstops remain primarily national, there can be no true Banking Union! Differences in the level of sovereign risk will remain relevant, and the continuing possibility of country-specific shocks will continue to demarcate banking markets. Political risks may further perpetuate fragmentation, because even those elements of the fiscal backstop which have been mutualized in the ESM are not characterized by automaticity, but require in each case of activation the unanimous agreement of the euro area's countries. Thus, the actual availability of the instruments can only be determined ex post facto, on the basis of a political process. This builds a significant element of ambiguity and unpredictability into the system and reduces its credibility. As the legacy assets of the pre-crisis period disappear and the quality of regulation is increasingly seen to depend on the actions of the ECB, rather than of the national authorities, it will become harder and harder to justify the need for national participation in burden sharing. Eventually, the Banking Union will require fully centralized and uniform resolution financing mechanisms.

\footnotetext{
156 This was exactly the point emphasized in the statement of the Euro Area Summit on 29 June 2012: When an effective single supervisory mechanism is established, involving the ECB, for banks in the euro area the ESM could, following a regular decision, have the possibility to recapitalize banks directly.'
} 